\title{
The relevance of defining trace metal baselines in coastal waters at a regional scale:
} The case of the Portuguese coast (SW Europe)

\author{
Juan Santos-Echeandía*, Miguel Caetano, Pedro Brito, Joao Canario, Carlos Vale \\ IPIMAR, National Institute of Biological Resources, Avenida Brasília 1446-006, Lisboa, Portugal \\ *Corresponding author: jecheandia@ipimar.pt
}

\section{Abstract}

The Water Framework Directives aims a reduction in concentration of hazardous substances in the marine environment. Consequently, there is a need to distinguish between anthropogenicaly influenced metal concentrations from natural background levels. To better achieve this goal in the Portuguese coast, dissolved and particulate trace metal (TM) concentrations along the Portuguese coast were determined in 46 sites distance 1-3 km from the shoreline. Dissolved values ranged within the following intervals: 0.01-0.89 nM for $\mathrm{Cd}$, 0.01-3.37 nM for Co, 0.90-45.4 nM for Cu, 3.30-140 pM for Hg, 1.88-15.1 nM for Ni, 0.01-0.15 $\mathrm{nM}$ for $\mathrm{Pb}$ and 1.40-62.0 nM for $\mathrm{Zn}$. Whereas $\mathrm{Cd}, \mathrm{Co}, \mathrm{Cu}, \mathrm{Ni}$ and $\mathrm{Zn}$ were enhanced in the southern coast, while $\mathrm{Pb}$ values were higher in the central part of the western coast. Mercury concentrations showed punctual increases all along the coast. Values of trace metals in suspended particulate matter varied in a broad range: 36-2902 $\mu \mathrm{mol} \mathrm{g}^{-1}$ for Al, 0.10-15.1 nmol $\mathrm{g}^{-1}$ for $\mathrm{Cd}$, $1.50-165 \mathrm{nmol} \mathrm{g}^{-1}$ for $\mathrm{Co}, 50.0-990 \mathrm{nmol} \mathrm{g}^{-1}$ for $\mathrm{Cu}, 2.80-76.4 \mathrm{nmol} \mathrm{g}^{-1}$ for $\mathrm{Hg}$, $22-$ $1471 \mathrm{nmol} \mathrm{g}^{-1}$ for $\mathrm{Ni}, 10.0-347 \mathrm{nmol} \mathrm{g}^{-1}$ for Pb and 416-10981 $\mathrm{nmol} \mathrm{g}^{-1}$ for $\mathrm{Zn}$. Higher values for $\mathrm{Al}, \mathrm{Ni}$ and $\mathrm{Co}$ were found in the central part of the western coast. However, $\mathrm{Cd}, \mathrm{Cu}, \mathrm{Pb}$ and $\mathrm{Zn}$ increased their levels from the north coast towards the central and south areas. The variability of both dissolved and particulate metals appears to be mainly associated with oceanographic conditions and continental inputs at North and central areas of the coast, and in the south coast to geological features rather than to anthropogenic pressures. On the basis of these results, regional baseline concentrations are proposed for the three typologies in Portuguese coastal waters defined under the Water Framework Directive.

Keywords: dissolved, particulate, metals, coastal waters, SW Europe, upwelling, poleward current, Pyritic Belt.

\section{INTRODUCTION}

The ocean margin is the critical land-ocean interface. At its inner boundary, coastal waters are characterized by steep physical and chemical gradients although being highly dynamic over short time-scales (Braungardt et al., 1998). Several studies have shown that coastal waters contain higher trace element concentrations than open ocean waters (eg., Bruland and Franks, 
1983; Kremling, 1985; Kremling and Hydes, 1988; Kremling and Pohl, 1989; Landing et al., 1995; Le Gal et al., 1999; Cotté, 1997). Natural weathering processes at basins of major world wide rivers have been pointed as major supplier of dissolved and particulate material to the ocean (Martin \& Meybeck, 1979). The enrichment of coastal waters in trace metals has been ascribed to river discharges (Martin and Whitfield, 1983), atmospheric transport (Martin et al., 1989), and anthropogenic sources (Cotté-Krief et al., 2000). Major internal sources are diagenetic exchanges of trace elements across the water-sediment interface (Klinkhammer et al., 1982; Cotté-Krief et al., 2000) and upwelling of bottom waters (Bruland et al., 1978, van Geen et al., 1990). Multiple factors influence the chemical speciation and water-particle partitioning of trace elements in coastal waters, namely complexation by dissolved organic matter, formation of colloids, precipitation, sorption to particulate phases and biological uptake (Muller, 1996, Morris et al., 1986, Olsen et al., 1982). In addition, accidental episodes of contamination may lead to punctual enhancement of trace-element concentrations. Examples are Aznalcollar mining spill (Grimalt et al., 1999; Achterberg et al., 1999; Elbaz-Poulichet et al., 2001), Erika and Prestige oil spills (Baars, 2002, Amiard et al., 2004, Chiffoleau et al., 2004, Prego and Cobelo-García, 2003, Santos-Echeandia et al., 2005, Santos-Echeandia et al., 2008). The intensity and extension of these contaminating events could not be determined if baseline concentrations are not previously established.

Trace-element concentrations in dissolved and suspended particulate matter (SPM) along the Portuguese coast are reported in a few works, covering the south and south-west sectors (van Geen et al., 1997, Cotté-Krief et al., 2000) and nearby estuarine mouths (Caetano and Vale, 2003). These works show a high variability in trace metal concentrations with several hypotheses to explain it. However, results with a high spatial resolution of the entire coast are still lacking.

The current work reports the $\mathrm{Cd}, \mathrm{Co}, \mathrm{Cu}, \mathrm{Hg}, \mathrm{Ni}, \mathrm{Pb}$ and $\mathrm{Zn}$ concentrations at 46 sites sampled in March 2010. Water was sampled within the first $3 \mathrm{~km}$ of the entire Portuguese coast, which correspond to the coastal waters defined within the Water Framework Directive. On the basis of these results, the anthropogenic influence and the regional differences are examined, and baseline concentrations of these elements for the three typologies of Portuguese coastal waters are proposed. 


\section{MATERIAL AND METHODS}

\subsection{Brief description of the Portuguese Coast}

The Portuguese coast is $943 \mathrm{~km}$ long. In the northern west coast, several funnel-shaped rivers discharge to coastal waters, like the Minho, Lima, Douro and Mondego rivers (annual average is $388 \pm 444 \mathrm{~m}^{3} \mathrm{~s}^{-1}, 74 \pm 64 \mathrm{~m}^{3} \mathrm{~s}^{-1}, 650 \pm 300 \mathrm{~m}^{3} \mathrm{~s}^{-1}, 2 \pm 3 \mathrm{~m}^{3} \mathrm{~s}^{-1}$ respectively, http://www.inag.pt) (Figure 1a). Higher freshwater discharges in winter induce stratification of the coastal waters (Moita, 2001). Conversely, the major rivers in the southwest coast, Tagus and Sado rivers (annual average is $324 \pm 436 \mathrm{~m}^{3} \mathrm{~s}^{-1}, 11 \pm 15 \mathrm{~m}^{3} \mathrm{~s}^{-1}$ respectively, http://www.inag.pt) end into large estuaries. Their morphology favors the trapping of river-borne material inside the estuaries under moderate to low flow conditions (Figure 1a). The Mira and Guadiana rivers (SW and $\mathrm{S}$ coast) have lower discharges $\left(3 \pm 3 \mathrm{~m}^{3} \mathrm{~s}^{-1}\right.$ and $37 \pm 59 \mathrm{~m}^{3} \mathrm{~s}^{-1}$, respectively, http://www.inag.pt) and estuaries consist of single channels. SPM concentration and Al concentration presented by Caetano and Vale (2003) evidenced the contrasting north-south influence of river inputs to the Portuguese coastal waters. Episodically, some of these estuaries receive abrupt quantities of freshwater and land-derived contaminants (Vale, 1990; Martins et al., 2005; Caetano and Vale, 2003; Quental et al, 2003). The geology of the north Portugal river basins is dominated by granitic complexes while the south is greatly influenced by the Iberian Pyritic belt (Munha et al., 1986) (Figure 1b), which is admittedly the largest sulphide mineralization in the world (Leistel et al., 1998). Weathering and mining activities have led to extremely high metal concentrations and acidity $(\mathrm{pH}<3)$ in the rivers crossing this belt (Delgado et al., 2009). The most densely populated areas in the Portuguese coast are Porto, Aveiro, Lisbon and Faro (Figure 1b) while the industrialized regions are located in the north part (Aveiro-Porto) and close to the Lisbon area.

Surface waters of the Iberian coast change circulation according to the season (Wooster et al., 1976; Frouin et al., 1990; Barton, 1998), being, in autumn-winter, northwards to the Bay of Biscay in France, and in spring-summer, it becomes weaker and reverses due to the North trade wind regime (Fiuza, 1983). This southward current promotes cooling and wind-induced upwelling along the shelf break (Fiuza, 1983; Abrantes and Moita, 1999). The Portuguese continental shelf is crossed by several canyons influencing the water circulation (Fiuza, 1983). The Nazaré canyon cuts-cross the NW continental shelf and has its head located close to the present-day shoreline. Northern from this canyon, coastal waters are characterized by a homogeneous upwelling of ENACW (Eastern North Atlantic Central Water) along the shore (Fiuza, 1983). From Lisbon to Cape Sines, the upwelling is affected by several canyon-systems 
like the Cascais, Lisbon and Setúbal canyons. South of the Cape Sines until Cape S. Vicente, the upwelling structure becomes more regular but is affected by warmer and saltier offshore surface waters (Moita et al., 2003). Finally, the southern Portuguese coast is controlled by a cyclonic gyre circulation in winter that turns anticyclonic in summer (Batteen et al., 2000; Mauritzen et al., 2001; García-Lafuente et al., 2006) affecting the entire Gulf of Cadiz. In addition, several studies have referred to a coastal current of warm water that flows westward near the shore, reaching Cape San Vicente and proceeds even northwards (Fiúza, 1983; Relvas and Barton, 2002; García-Lafuente et al., 2006) reaching the Spanish NW coast. The presence of eddies derived from the Mediterranean Sea has been reported offshore the south coast of Portugal (Brogueira et al., 2004).

Within the Water Framework Directive three typologies for the Portuguese coast have been defined (Bettencourt, 2004; Ferreira et al., 2005): A5 - Mesotidal exposed Atlantic coast, from the Minho estuary until Cape Carvoeiro; A6 - Mesotidal moderately exposed Atlantic coast, between this cape and the Ponta da Piedade; and A7 - Mesotidal sheltered Atlantic coast, until the Guadiana estuary.

\subsection{Sampling and samples pretreatment}

The sampling campaign along the Portuguese Coast (Fig. 1) was performed between the $16^{\text {th }}$ -

$22^{\text {nd }}$ March 2010 on board the R/V Noruega; 46 surface water samples were collected from Minho to Guadiana River (Figure 1) at 1-3 km distance from the shoreline. An important precipitation in Portugal $(115 \mathrm{~mm})$ was measured during the first two weeks of March in comparison with the ancillary data registered for this period of the year (INAG). Consequently, high river flows are expected. In addition, favorable upwelling indexes (Figure 2) were measured during the first couple of days (CCMP: http://podaacwww.jpl.nasa.gov/datasetlist?search=ccmp ) while the sampling cruise was collecting samples between Carvoeiro Cape and Minho river mouth (Figure 1). Surface samples (0.5 $\mathrm{m}$ below the surface) were pumped into a class-100 laminar flow bench located in the lab onboard with the aid of a tow-fish to be filtered through $0.45 \mu \mathrm{m}$ acetate cellulose syringe filters (Millipore). In addition, a depth profile (DP, $1800 \mathrm{~m}$ ) was sampled north to the Tagus estuary using a Kevlar cable and Teflon coated Niskin bottles with external closure (Fig. 1). After filtration, around $100 \mathrm{~mL}$ of the water was acidified to $\mathrm{pH} \approx 2$ with $\mathrm{HCl}$ Trace Select (Fluka) for TMs analysis while $10 \mathrm{~mL}$ were stored in pre-cleaned HDPE vials and frozen at $-20^{\circ} \mathrm{C}$ pending nutrient analysis. In the case of mercury, an aliquot of each sample was directly transferred to a previously decontaminated quartz flask while another aliquot was filtrated with a $0.45 \mu \mathrm{m}$ to a previously 
decontaminated quartz flask (around $40 \mathrm{~mL}$ ) and preserved with a bromide monochloride (BrCl) solution (EPA Method 1631). Furthermore, between 1 and $2 \mathrm{~L}$ of water were collected for SPM quantification. Water was filtered using acid-washed polycarbonate filter holder through acid cleaned acetate cellulose Nuclepore filters $(0.45 \mu \mathrm{m}$ and $47 \mathrm{~mm})$. Filters were placed inside Petri dishes and frozen pending particulate trace elements analysis. Finally, around two liters of water were filtered through $0.7 \mu \mathrm{m}$ GFF filters for chlorophyll measurements. Samples for chlorophyll $a$ were kept at dark conditions under refrigerated environment and were filtered through a filtration slope as soon as possible. Samples were frozen at -18 으 during the cruise and immediately analyzed as returned to the laboratory. The maximum storing time was five days.

\subsection{Measurement of master variables}

A previously calibrated multiparametric probe and a Seabird 911 plus CTD were used for direct measurement of temperature, salinity, dissolved oxygen and $\mathrm{pH}$ in surface waters from the vessel. The $\mathrm{pH}$ was measured with a glass electrode (Mettler) calibrated with the following Merck buffer solutions $4.0 \pm 0.1,7.0 \pm 0.1$ and $10.01 \pm 0.1$. The oxygen was not measured on CTD but in a Yellow Spring Instrument model 605QS probe calibrated with a 0\% oxygen solution and with a $100 \%$ oxygenated solution according to the YSI procedure. The errors for temperature, salinity, $\mathrm{pH}$, dissolved oxygen and SPM are $0.1 \%, 0.1 \%, 0.1$ units, $2.0 \%$ and $1.0 \%$.

\subsection{Analytical procedure}

Dissolved (TMs) concentrations were determined by means of stripping voltammetry using a Metrohm797 VA computrace equipped with a hanging mercury drop electrode (HMDE) as the working electrode, $\mathrm{Ag} / \mathrm{AgCl}$ as the reference electrode, and a Pt wire as the counter-electrode. Prior to determination, samples were UV-digested for $1 \mathrm{~h}$ using an UV-Digestor equipped with a high-pressure mercury lamp of 200 W (Achterberg and Van Den Berg, 1994). The simultaneous determination of $\mathrm{Cd}, \mathrm{Cu}, \mathrm{Pb}$ and $\mathrm{Zn}$ in the dissolved phase was carried out using the method of standard additions by differential pulse anodic stripping voltammetry (DPASV) (Gardiner and Stiff., 1975) while the simultaneous determination of Co and Ni was performed by Adsorptive Cathodic Stripping Voltammetry (ACSV) (Santos-Echeandía., 2011). The solution was deaerated by purging $(5 \mathrm{~min}$ ) with nitrogen. Voltammetric parameters for the DPASV method were: deposition $300-900 \mathrm{~s}$ at $-1.1 \mathrm{~V}$ whilst stirring; $10 \mathrm{~s}$ quiescence at $-1.1 \mathrm{~V}$; potential scan using the differential pulse modulation: pulse amplitude of $50 \mathrm{mV}$, a pulse 
168 duration of $40 \mathrm{~ms}$, a pulse frequency of $5 \mathrm{~s}^{-1}$ and a scan rate of $20 \mathrm{mV} \mathrm{s}$, from -1.1 to $0 \mathrm{~V}$. In 169 the case of the ACSV method, voltammetric parameter were: deposition 30-120 s at $-0.35 \mathrm{~V}$ 170 whilst stirring; $10 \mathrm{~s}$ quiescence at $-0.05 \mathrm{~V}$; potential scan using the differential pulse 171 modulation: pulse amplitude of $50 \mathrm{mV}$, a pulse duration of $40 \mathrm{~ms}$, a pulse frequency of $5 \mathrm{~s}$ 172 and a scan rate of $20 \mathrm{mV} \mathrm{s}^{-1}$, from $-0.05 \mathrm{~V}$ to $-1.2 \mathrm{~V}$.

173 One blank was run every five samples and results were blank-corrected. The accuracy of the 174 analytical procedure was assessed by the analysis of two different certified reference materials 175 (CRMs) (CASS-4 and SLEW-3), obtaining good agreement with the certified concentrations 176 (Table 1). The detection limits of the analytical procedure, defined as three times the standard 177 deviation of the blanks, were $0.4 \mathrm{nM}$ for $\mathrm{Ni}, 0.020 \mathrm{nM}$ for $\mathrm{Co}, 0.5 \mathrm{nM}$ for $\mathrm{Zn}, 0.7 \mathrm{nM}$ for $\mathrm{Cu}$, $1780.010 \mathrm{nM}$ for $\mathrm{Pb}$ and $0.010 \mathrm{nM}$ for $\mathrm{Cd}$. The precision of the method measured as relative standard deviation was: 5-10\% for $\mathrm{Ni}$ (at $6 \mathrm{nM}$ ), 3-6\% for Co (at $0.5 \mathrm{nM}$ ), 5-10\% for Zn (at 20 nM), 5-10\% for $\mathrm{Cu}$ (at $10 \mathrm{nM}$ ), 5-10\% for $\mathrm{Pb}$ (at 300 pM) and 25-40\% for Cd (at 60 pM). In the case of total dissolved $\mathrm{Hg}$, prior to analysis by Cold Vapour Atomic Fluorescence Spectroscopy (CV-AFS) each filtered sample was sequentially reduced with $\mathrm{NH}_{2} \mathrm{OH} . \mathrm{HCl}$ to destroy the free halogens and with stannous chloride $\left(\mathrm{SnCl}_{2}\right)$ to convert $\mathrm{Hg}(\mathrm{II})$ to volatile $\mathrm{Hg}(0)$ (EPA Method 1631). Accuracy and precision were determined after preparing different stock solutions of $\mathrm{Hg}^{2+}$ from $1000 \mathrm{ppm}$ Merck stock solution in $2 \% \mathrm{HNO}_{3}$. These solutions were prepared and measured every 2 samples. Detection limit and precision error were 0.5 pM and $4.0 \%$ respectively $(p<0.05)$. Procedural blanks were prepared the same way as samples with Milli-Q water instead of water samples and using the same reagents. The fluorescence signal of the blanks was always lower than detection limit.

Filters charged with SPM were completely mineralized with $1 \mathrm{~cm}^{3}$ of HF (40\%) and $1 \mathrm{~mL}$ of Aqua-Regia ( $\mathrm{HCl}-36 \%: H N O 3-60 \% ; 3: 1)$ in closed Teflon bombs at $100{ }^{\circ} \mathrm{C}$ during $1 \mathrm{~h}$. The bomb contents were evaporated to near dryness in Teflon vials, taken up with $\mathrm{HNO}_{3}$, heated for 20 min at $75^{\circ} \mathrm{C}$ and diluted to $50 \mathrm{~mL}$ with Milli-Q water. Concentrations of $\mathrm{Cd}, \mathrm{Co}, \mathrm{Cu}, \mathrm{Ni}, \mathrm{Pb}$ and Zn were determined using a quadrupole ICP-MS (Thermo Elemental, X-Series) equipped with a Peltier Impact bead spray chamber and a concentric Meinhard nebulizer. A 7-points calibration within a range of $1-100 \mu \mathrm{L} \mathrm{L}^{-1}$ was used to quantify metal concentration. Coefficients of variation for metal counts $(n=5)$ varied between 0.5 and $2 \%$. The precision and accuracy of each metal concentration measurements were determined through repeated analysis of CRMs (MESS2 and PACS2), using Indium as internal standard, were 1-4\% and 2-5\%, respectively. Procedural blanks always accounted for less than $1 \%$ of the total metal concentrations in 
samples. Mercury concentration in the particulate matter was calculated by subtraction of the total mercury determined in filtered water samples from total mercury concentrations in unfiltered samples. This methodology is frequently used for the determination of particulate $\mathrm{Hg}$ and methyl mercury in aquatic systems. The result was then multiplied by the concentration of SPM to obtain particulate mercury concentration in $\mu \mathrm{g} / \mathrm{g}$.

Finally, chlorophyll a was determined by the spectrophotometer method (Lorenzen, 1967) while the ammonium $\left(\mathrm{NH}_{4}{ }^{+}\right)$, nitrate $\left(\mathrm{NO}_{3}{ }^{-}\right)$, nitrite $\left(\mathrm{NO}_{2}{ }^{-}\right)$, phosphate $\left(\mathrm{HPO}_{4}{ }^{2-}\right)$ and silicate $\left(\mathrm{H}_{4} \mathrm{SiO}_{4}\right)$ were determined using a Skalar autoanalyser following the methodology described by Hansen and Grasshoff (1983). The detection limits were $0.01 \mu \mathrm{M}$ for nitrate, $0.02 \mu \mathrm{M}$ for nitrite, $0.07 \mu \mathrm{M}$ for ammonium, $0.03 \mu \mathrm{M}$ for phosphate and $0.05 \mu \mathrm{M}$ for silicate. Dissolved inorganic nitrogen (DIN) was calculated as the sum of ammonium, nitrate and nitrite.

\subsection{Statistics}

Prior to statistical analyses, the log-normal of partition coefficient of each metal $\left(\log K_{D}(M e)\right)$ were tested for normality and equality of variances. Non-compliance with parametric ANOVA assumptions led to employment of the Kruskal-Wallis $\mathrm{H}$ and Mann-Whitney non-parametric tests to evaluate the existing differences between log $K_{D}$ registered from samples in the west Portuguese coast and south coast. The significance for statistical analyses was always $p<0.05$. The statistical analyses were performed using STATISTICA 6 (Statsoft).

\section{RESULTS}

\subsection{Oceanographic conditions and master variables}

Figure 3 shows the satellite images with the average conditions of temperature, salinity and chlorophyll $a$ obtained during the water sampling period $\left(16^{\text {th }}-22^{\text {nd }}\right.$ March). Temperature ranged from $12^{\circ} \mathrm{C}$, at the north coast of Portugal to $20^{\circ} \mathrm{C}$ close to Guadiana (south-east coast). Salinity ranked from 34 to 37 with lower values in areas adjacent to the estuaries of Douro (27), Tagus (33) and Guadiana (29). Chlorophyll a ranged between 1-10 $\mathrm{mg} \mathrm{m}^{-3}$, with higher values at the north coast, between Minho and Mondego, in the Sado area and close to Santa Maria Cape. The lowest values were observed between Cabo Carvoeiro and Tagus estuary mouth.

Figure 4 shows the registered values of $\mathrm{S}, \mathrm{T}$, chl a, dissolved oxygen and SPM concentration. Salinity, $\mathrm{T}$ and $\mathrm{chl} a$ were within the intervals of the satellite image data despite their broader spatial resolution. Dissolved oxygen concentrations varied between 5.5 and $8.4 \mathrm{mg} \mathrm{L}^{-1}$ with higher values at the north coast of Portugal (Figure 4d). Saturation was in general above $80 \%$, 
with the exception of areas located between the mouth of the Mondego and Tagus estuary (68-79\%). SPM concentration varied between 0.60 and $14.4 \mathrm{mg} \mathrm{L}^{-1}$ (Figure 4e). The higher values found in the proximities of the Douro, Ria of Aveiro, Tagus and Ria Formosa reflect the influence of the plumes of the respective estuaries and lagoon. The lower values were registered between Mondego and Cabo da Roca, and from Sado to S. Vicente Cape, which correspond to the areas with low river discharges (Fig.1).

\subsection{Nutrients}

Figure 5 shows dissolved inorganic nitrogen (DIN), phosphate and silicate concentrations in the surveyed sites. The distribution pattern is characterized by pronounced differences among sites. Phosphate concentrations in the area adjacent to the Tagus estuary were up to 50 times (3.1-15 $\mu \mathrm{M})$ above the mean of all the other sampling sites (0.1-0.5 $\mu \mathrm{M})$. The pattern found for DIN displayed an irregular variation. Despite the higher values in the Tagus adjacent area (4.0$17 \mu \mathrm{M})$, enhancements were also registered in other sites along the coast (0.5-4.0 $\mu \mathrm{M})$. Silicate distribution was also variable with concentrations varying between 0.06 and $11.0 \mu \mathrm{M}$. Unlike the other nutrients, the highest values of silicate were not found nearby the Tagus estuary.

\subsection{Dissolved trace elements}

250

Figure 6 presents the concentration intervals of $\mathrm{Cd}, \mathrm{Co}, \mathrm{Cu}, \mathrm{Hg}, \mathrm{Ni}, \mathrm{Pb}$ and $\mathrm{Zn}$ in the dissolved fraction of surface waters from the 46 surveyed sites. Three distribution patterns can be discerned along the coast. Levels of dissolved $\mathrm{Cd}(0.01-0.89 \mathrm{nM}), \mathrm{Cu}(0.90-45.0 \mathrm{nM})$ and $\mathrm{Zn}$ (1.40-62.0 nM) were much higher in the south-western and southern coastal waters (WFD type A6 and A7, respectively) than north of the Tagus (WFD type A5 and part of A6). Cobalt (0.03$3.40 \mathrm{nM}$ ) and $\mathrm{Ni}(1.90-15.0 \mathrm{nM})$ showed a similar pattern to those elements, although with enhanced values in the coastal areas nearby the Minho and Lima. Enhanced Hg concentrations were registered in several sites (5.00-140 pM) namely near the mouth of certain estuarine systems (i.e. Minho, Cavado, Tagus, Ria Formosa and Guadiana, Figure 1). Lead concentrations (0.01-0.15 nM) were higher in the central part of the Portuguese coast, particularly adjacent to Sado and Tagus areas, and lower levels at the southern coast. Depth variation of temperature and salinity in the offshore station is shown in Figure 7. The profiles evidenced that the upper $400 \mathrm{~m}$ of the water column is characterized by North Atlantic Central Water. Enhanced values of salinity and temperature between 800 and $1200 \mathrm{~m}$ pointed to a Mediterranean Water mass (MW). Deeper the cold and less saline North Atlantic Deep Water mass was found. Higher concentrations of $\mathrm{Cu}$ and $\mathrm{Pb}$ were registered at surface waters than in deeper waters. Otherwise, levels of $\mathrm{Cd}, \mathrm{Zn}, \mathrm{Ni}$ and $\mathrm{Co}$ increased with the depth with a maximum in the MW. 
Figure 8 presents the interval concentrations of $\mathrm{Al}, \mathrm{Cd}, \mathrm{Co}, \mathrm{Cu}, \mathrm{Hg}, \mathrm{Ni}, \mathrm{Pb}$ and $\mathrm{Zn}$ in the SPM along the Portuguese coast. A broad range of particulate $\mathrm{Al}\left(36-2902 \mu \mathrm{mol} \mathrm{g}^{-1}\right)$ was found along the coast, with higher values from Carvoeiro Cape to Sines Cape and some hotspots closer to Douro, Guadiana and Ria Formosa. Lower Al concentrations were found in the south-west and south coasts $\left(<200 \mu \mathrm{mol} \mathrm{g}^{-1}\right)$. Cobalt $\left(1.50-170 \mathrm{nmol} \mathrm{g}^{-1}\right)$ and $\mathrm{Ni}\left(22-1475 \mathrm{nmol} \mathrm{g}^{-1}\right)$ showed a similar distribution pattern to Al. Cadmium (0.03-15.0 nmol g$\left.{ }^{-1}\right), \mathrm{Cu}\left(50.0-600 \mathrm{nmol} \mathrm{g}{ }^{-1}\right), \mathrm{Pb}$ (10.0-300 $\left.\mathrm{nmol} \mathrm{g}^{-1}\right)$ and $\mathrm{Zn}\left(530-11000 \mathrm{nmol} \mathrm{g}^{-1}\right)$ exhibited a different distribution pattern characterized by lower concentrations in the SPM from the northern coastal waters than from the south of Carvoeiro Cape. Higher values were found in particles collected in the proximities of the Sado and Tagus estuaries. Mercury $\left(4.0-80 \mathrm{nmol} \mathrm{g}^{-1}\right)$ showed an irregular distribution with several punctual high values along the coast, mainly near estuarine systems (i.e. Minho, Cavado, Tagus, Ria Formosa and Guadiana, Figure 1).

\subsection{Element/Al molar ratios}

Figure 9 shows the trace-element/Al molar ratios, as commonly used in order to minimize the particle nature and size effect (Windom et al., 1989; Loring, 1990; Pohl et al., 2004). This representation highlights the trace element enrichment observed in the suspended particles from the southwest and south coast. Ratios pointed to enrichment of all determined elements except $\mathrm{Co}$ in areas adjacent to the Tagus and Sado estuaries. In addition $\mathrm{Cu}, \mathrm{Ni}, \mathrm{Zn} \mathrm{Cd}, \mathrm{Pb}$ and $\mathrm{Hg}$ showed high ratios to Al near Sines Cape and southern coast. For most of the determined elements, ratios increased between the Ria Formosa and the Guadiana, being Co the most remarkable case.

\subsection{Dissolved-Particle interactions $\left(K_{D}\right)$}

Assuming quasi-equilibrium conditions between the water and the suspended particulate matter, the partitioning of trace element between dissolved and particulate fractions can be estimated by the distribution coefficient, defined as $K_{D}=[P] /[D]\left(\mathrm{L} \mathrm{kg}^{-1}\right)$, where $[P]$ represents the particulate trace element concentration $(w / w)$ and [D] the dissolved trace element concentration (w/v) (Millward and Turner, 1995). Calculated mean values and standard deviation of $\log K_{D}$ were: $4.1 \pm 0.5(\mathrm{Cd}), 5.2 \pm 0.7(\mathrm{Co}), 4.7 \pm 0.5(\mathrm{Cu}), 6.1 \pm 0.6(\mathrm{Hg}), 4.5 \pm 0.4(\mathrm{Ni})$, 6.1 $\pm 0.6(\mathrm{~Pb})$ and $5.2 \pm 0.4(\mathrm{Zn})$. The decreasing sequence was $\mathrm{Hg} \approx \mathrm{Pb}>\mathrm{Zn}>\mathrm{Co}>\mathrm{Cu}>\mathrm{Ni}>\mathrm{Cd}$, within an interval of two orders of magnitude for $\log \mathrm{K}_{\mathrm{D}}$. Although the coefficient variation of the mean was in general lower than $15 \%, \log \mathrm{K}_{\mathrm{D}}$ of $\mathrm{Ni}, \mathrm{Zn}, \mathrm{Cd}, \mathrm{Co}$ and $\mathrm{Cu}$ were significantly $(\mathrm{p}<0.05)$ 
and A6). Conversely, the $\log K_{D}(P b)$ showed an opposite trend being significantly $(p<0.05)$ higher at the south coast. No significant differences $(p>0.05)$ were found for $\log K_{D}(\mathrm{Hg})$.

\section{DISCUSSION}

Despite the discharge of several rivers on the A5 typology coastal waters, the current work shows low concentrations of nutrients and trace elements, as observed in previous works in the NW coast of Iberian Peninsula (Santos-Echeandia et al., 2005; Santos-Echeandia et al., 2009) or North Atlantic Ocean waters (Landing et al. 1995, Saager et al. 1997, Ellwood and van den Berg 2001, and Cotté-Krief et al. 2002). This pattern points to minor contribution of rivers to the dissolved trace elements composition of near-shore coastal waters, probably due to the presence of upwelling events that would retain the continental waters in the mouth of the estuaries. A similar pattern was found for trace elements in A6 coastal waters (Table 2). Dissolved inorganic nitrogen and phosphate increased clearly near the Tagus estuary and northwards presumably as a result of urban and industrial pressures from the Lisbon metropolitan area ( $\approx 5$ million inhabitants, GeoNames). Conversely, in the A7 typology (south Portuguese coastal waters) trace metal concentrations rise up 30 times the values found for A5 and A6. These values were similar to those reported in south Spanish shelf waters (van Geen 1991; Cotté-Krief et al., 2000; van Geen et al., 1997). It is noteworthy that element concentrations all over the coast, in both dissolved and particulate fractions, varied up to 2-3 orders of magnitude. These intervals may be related to the narrow ban where surface waters were sampled, between the coastline and closure line of coastal waters defined in Water Framework Directive (Ferreira et al, 2005). The calculated values of $\log \mathrm{K}_{\mathrm{D}}$ are comparable to the ones reported for other coastal systems (Balls, 1989 and references therein), suggesting that affinity of trace elements to suspended matter is of major importance on the waterparticle partitioning. The adsorption tendency has been related to the first hydrolysis constant of the element (Stumm and Morgan, 1981). Previous studies have shown the tendency of dissolved lead to adsorb onto suspended particles decreasing the concentrations in solution (Windom et al., 1989; Balls et al., 1994; Chiffoleau et al., 1994; Chiffoleau et al., 1999; CobeloGarcía et al., 2005). However, cadmium showed the lowest log $K_{D}$, probably due to its association with chloride ions (Comans et al., 1988) and to its strong association with organic matter (Bruland, 1992). According to this author at least $70 \%$ of dissolved $\mathrm{Cd}$ in surface waters is in the form of organic complex. Strong $\mathrm{Cd}$ complexation may avoid binding to particles and thus diminishing log $K_{D}$ values. Despite of these processes, most log $K_{d}$ of the determined 
elements, except $\mathrm{Pb}$, were lower at the south coast of Portugal. Concentrations, element/Al ratios and $K_{D}$ may thus reflect small-scale spatial variation related to different coastal morphology and associated oceanographic processes, as well as river inputs.

The presumed geographical pattern observed along the Portuguese coast is better illustrated by the application of a principal component analysis (PCA) with the results presented in Figure 10. The southern stations, presenting enhanced metal concentrations, are projected separately from the stations of the northern region. Moreover, the samples located in the river or estuaries outflows are also well grouped (Figure 10). Attending to this, three different features that take control over trace metal distribution can be distinguished along the coast.

\subsection{Upwelling conditions}

The lower temperatures at the northern coastal waters are related to the occurrence of upwelling conditions during the campaign confirmed by the positive upwelling indexes measured (Figure 2), which is in line with recurrent episodes registered in this season at this region (Wooster et al., 1976; Fiuza, 1983; Relvas et al., 2007). Although nutrient concentrations did not mirror the upwelling of nutrient enriched waters, chlorophyll $a$ presented enhanced values presumably due to the consumption of nutrients advected from bottom waters. These results are in line with the exceptionally high chlorophyll values registered in winter (Abrantes and Moita, 1999). In addition, typical spring chained-like diatoms blooms composed mainly by Chaetoceros decipiens, Detonula pumila, Dytilum brightwelli and Lauderia annulata have been found in the A5 area (Moita, T., personal communication) associated with the higher values of chlorophyl a what would reinforce the upwelling hypothesis.

Dissolved $\mathrm{Co}, \mathrm{Hg}, \mathrm{Ni}$ and $\mathrm{Pb}$ were enhanced in surface waters from the northern Portuguese coast adjacent to rivers Minho, Lima and Douro. Nevertheless it is uncertain whether these increases are attributed to upwelling, local feature or anthropogenic inputs. However, $\mathrm{Hg}$ and $\mathrm{Pb}$ are probably associated to river inputs since their concentrations enhance close to the estuaries. Otherwise, $\mathrm{Co}$ and $\mathrm{Ni}$ could be related to upwelling processes. In fact, depth profiles evidence enhanced levels of these elements with depth (Figure 7). In addition, $\mathrm{Pb}$ and $\mathrm{Cu}$ concentrations decreased in the first $200 \mathrm{~m}$ of the water column (Figure 7). These results pointed that upwelling will result in the $\mathrm{Co}$ and $\mathrm{Ni}$ enrichment and in diminishing of $\mathrm{Pb}$ concentrations. It has been reported for the Iberian Atlantic coast either a decrease in dissolved $\mathrm{Cu}, \mathrm{Pb}$ and $\mathrm{Zn}$, or an enhancement in $\mathrm{Cd}, \mathrm{Ni}$ and $\mathrm{Co}$ during upwelling events happened (Cotté-Krieff et al., 2000; Santos-Echeandia et al., 2009). Increased metal 
concentrations have been observed in other regions under frequent upwelling events (e.g., the Celtic Sea: Cotté-Krief et al., 2002; San Francisco Bay: van Geen and Luoma, 1993).

\subsection{River/estuarine inputs}

The Portuguese coastline contains various morphological irregularities constituted by capes, funnel-shaped estuaries, bays, broad estuaries, and coastal lagoons with permanent connection to the sea. The plumes of the Douro, Tagus and Guadiana rivers were marked by the salinity decrease, unlike freshwater discharges by estuaries of small rivers were not clearly discerned in the salinity distribution along the coast at first glance. The pronounced increases of DIN and phosphate concentrations evidence the influence of Tagus discharges on the nearby coastal area. Two factors may have concurred to this pattern: the large water volume of the estuary exchanged with the sea over semi-diurnal tidal scales; and the naturally turbid water of the estuary (Vale and Sundby, 1987) inducing a light limitation to convert nutrients into primary production. The Douro signal was minor and the input from other estuaries was poorly marked. The silicate distribution was less clear with several peaks concentrations along the coast. The estuarine water input into the coastal waters was poorly marked by metal concentration distributions, both in dissolved and particulate forms. Although the dissolved fraction of several elements presented enhanced concentrations in areas nearby the Minho, Douro and Tagus (eg., $\mathrm{Co}, \mathrm{Hg}, \mathrm{Ni}, \mathrm{Pb}$ ) elevated values were also registered in other areas of the coast far from the direct influence of river inputs. Strong negative correlations $(n=34)$ between salinity and dissolved metal concentrations have been found for: $\mathrm{Ni}\left(\mathrm{R}^{2}=0.82\right)$; $\mathrm{Co}\left(\mathrm{R}^{2}=0.79\right) ; \mathrm{Cu}$ $\left(R^{2}=0.65\right) ; C d\left(R^{2}=0.62\right)$ and; $Z n\left(R^{2}=0.52\right)$. This suggests the influence of freshwater inputs that may superimpose the role of chloride or organic complexes and nanoparticle formation in metal chemistry. On the contrary, weak correlations between $\mathrm{Pb}$ or $\mathrm{Hg}$ and salinity $\left(\mathrm{R}^{2}<0.3\right)$ suggest that other parameters than chlorine ions influences the distribution of these elements in the water column. The variation of the trace-element/Al ratios did not show a clear relation to the river inputs.

\subsection{Geographical patterns}

The highest concentration of several trace elements either in dissolved or particulate fractions was registered in the south and southwest coast of the Portuguese coast (Figures 6 and 8). The enhancements were more accentuated for dissolved $\mathrm{Cd}, \mathrm{Co}, \mathrm{Cu}$ and $\mathrm{Zn}$, while less clear differences were found for $\mathrm{Hg}$ and $\mathrm{Ni}$. Lead, was the only elements with low concentrations in found in the particulate phase. Several factors converge in this area. Firstly, the Guadiana River 
drains the central-western part of the Iberian Pyrite Belt (Figure 1), an area with many polymetallic sulfide deposits and residues of mining activities (Leistel et al., 1998). Under oxidizing conditions it generates an acidic leachate with high quantities of sulfur species, metals, and metalloids in solution (Delgado et al., 2009). Furthermore, the observed increase of metal concentrations in the Mediterranean water mass has already been reported in other works nearby the Strait of Gibraltar (Statham et al., 1985; van Geen et al., 1988) A coastal current of warm water that flows westward near the shore reaches the Cape San Vicente and, even, proceeds northwards (Fiúza, 1983; Relvas and Barton, 2002; García-Lafuente et al., 2006) reaching the northwestern coast of Spain. The effect of this current was noticeable close to Sines Cape by temperature satellite image (Figure 3a). Finally, the south coast of Portugal is near the metal enriched rivers Guadalquivir and Tinto that reach the south coast of Spain (Elbaz-Poulichet et al., 2001; Sarmiento et al., 2011). The enhanced metal concentrations have been reported for the south coast of Portugal invoking similar explanations (van Geen and Boyle, 1990; van Geen et al., 1997; Braungardt et al., 1998; Achterberg et al., 1999; Cotte-Krief et al., 2000; Beckers et al., 2007). The higher spatial resolution of the sampling sites and the extension of the surveyed area corroborate those previous findings.

4.4.An attempt to define trace element baseline concentrations and comparison to other European coastal areas

On the basis of the results obtained with this high spatial resolution it was attempted to establish the baseline concentrations for $\mathrm{Cd}, \mathrm{Co}, \mathrm{Cu}, \mathrm{Hg}, \mathrm{Ni}, \mathrm{Pb}$ and $\mathrm{Zn}$ at each typology of the Portuguese coast (A5, A6 and A7 of the Water Framework Directive). The methodology for estimating the baseline values of these elements were the following: (i) at each typology, selection the $20 \%$ of the sites presenting the lowest element concentrations; (ii) at each typology, calculation of the concentration interval of each determined element for the selected sites (Table 2). Low levels of trace elements in the A5 and A6 typologies point to minor influence of anthropogenic pressures at the coastal waters of west coast of Portugal. However, punctual increases of metal concentrations occur at northern coast of A5 associated with high river flows following heavy rain periods (Caetano and Vale, 2003). Elevated dissolved $\mathrm{Cd}, \mathrm{Co}, \mathrm{Cu}, \mathrm{Hg}, \mathrm{Ni}$ and $\mathrm{Zn}$ were found at the south Portuguese coast (A7 typology) except for $\mathrm{Pb}$, mainly associated with particles (high log $\mathrm{K}_{\mathrm{D}}$ ). Baseline concentrations of $\mathrm{Cu}, \mathrm{Co}$ and $\mathrm{Cd}$ in A7 were 20 to 30 times above the values proposed for A5 and A6, while only 5 and 2 times were found for $\mathrm{Ni}$ and $\mathrm{Hg}$, respectively.

As indicated before, there is an important lack of studies about trace metal concentration along the European coasts. In the context of the Water Framework Directive, a unique work 
has been published regarding trace metal concentration in coastal waters (Tueros et al., 2008).

434 Background levels of heavy metals ( $\mathrm{As}, \mathrm{Cu}, \mathrm{Mn}, \mathrm{Ni}, \mathrm{Pb}$ and $\mathrm{Zn}$ ), in coastal waters within the

435 Basque Country (northern Spain), according to ranges are estimated. This study, together with

436 other European coastal and open ocean waters studies where dissolved and particulate trace metal concentrations are reported have been summarized in Table 3 and Table 4. Dissolved trace metal concentrations in the Portuguese coast are within the values reported for other European coastal waters or North East Atlantic Ocean waters (Table 3) with the exception of the A7 typology (Table 2). However, the values reported in this study for the A7 typology, are quite similar to the ones reported for the Basque Country coastal waters (Tueros et al., 2008). Regarding the particulate metals, we find a similar scenario, with similar levels between this study and other European coastal or open ocean waters (Table 4) with the exception of the A7 typology.

\section{CONCLUSIONS}

The high variability of trace element concentrations registered in this study points to the importance of examining concentration patterns at a regional scale. These changes may result from anthropogenic effects as well as natural factors (i.e. oceanographic and hydrographic conditions and geological features). It seems that geological features of the SW and S Portuguese coast superimpose fluvial or oceanographic conditions in defining the trace element distribution, both in dissolved and particulate fractions of this area. However, riverine inputs and upwelling conditions determine trace element concentrations in the North coast. Only punctual concentrations exceed the baseline values at each typology. The estimation of baseline values and the influence of anthropogenic pressures are important at European level for the implementation of the Water Framework Directive and Marine Strategic Framework Directive. European state-members should supply information of descriptors related to contamination in order to assessing Good Environmental Status. Due to the variability of oceanographic and climate conditions all over the coast further studies involving the characterization of the water column should considered the seasonal pattern contributing, thus, to a better definition of baseline concentrations.

Aknowledgements: The authors would like to thank the crew of the R/V Noruega, Milu and Rute for their kind sampling cooperation during the sampling campaign. Dr. Bernárdez and Dr. Costas for their help with the figures and Dr. Raimundo for the statistical treatment. The authors thank the NERC Earth Observation Data Acquisition and Analysis Service (NEODAAS) 
Government for financial support (post-doctoral contract).

\section{REFERENCES}

471

- Abrantes, F., Moita, M., 1999. Water column and recent sediment data on diatoms and coccolithophorids, off Portugal, confirm sediment record of upwelling events. Oceanologica Acta 22, 319-336. samples for trace metal determination using an automated voltammetric system. Analytica Chimica Acta 291, 213-232.

- Achterberg, E.P., van den Berg, C.M.G., 1996. Automated monitoring of Ni, Cu and $\mathrm{Zn}$ in the Irish Sea. Marine Pollution Bulletin 32, 471-479.

- Achterberg, E.P., Braungardt, C., Morley, N.H., Elbaz-Poulichet, M.L., 1999. Impact of Los Frailes mine spill on riverine, estuarine and coastal waters in the southern Spain. Water Research 33, 3387-3394.

- Alves, F.L., da Silva, C.P., Pinto, P., 2007.The Assessment of the Coastal Zone Development at a Regional Level - the Case study of Portugal Central Area. Journal of Coastal Research 50, 72-76.

- Amiard, J.C., Bacheley, H., Barillé, A.L., Barillé, L., Geffard, A., Himery, N., 2004. Temporal changes in nickel and vanadium concentrations and in condition index and metallothionein levels in three species of mollusks following the Erika oil spill. Aquatic Living Resources 17, 281-288.

- Baars, B.J., 2002. The wreckage of the oil tanker Erika - human health risk assessment of beach cleaning, sunbathing and swimming. Toxicological Letters 128, 55-68.

- Balls, P.W., 1989. The partition of trace metals between dissolved and particulate phases in European coastal waters: a compilation of field data and comparison with laboratory studies. Netherland Journal of Sea Research 23, 7-14.

- Balls, P.W., Laslett, R.E., Price, N.B., 1994. Nutrient and trace metal distributions over a complete semi-diurnal tidal cycle in the Forth estuary, Scotland. Netherland Journal of Sea Research 1, 1-17.

- Barton, E.D., 1998. Eastern boundary of the North Atlantic: North West Africa and Iberia, in: Robinson, A.R., Brink, K.H. (Eds.). The Sea. Wiley, pp. 633-657.

- Batteen, M.L., Martinez, J.R., Bryan, D.W., Buch, E.J., 2000. A modeling study of the coastal eastern boundary current system off Iberia and Morocco. Journal of Geophysical Research 105, 14173-14195.

- Beckers, J.M., Achterberg,, E.P., Braungardt, C., 2007. Comparison of high spatial resolution trace metal distributions with model simulations for surface waters of the Gulf of Cadiz. Estuarine Coastal and Shelf Science. 74, 692-702.

- Beiras, R., Fernandez, N., Gonzalez, J.J., Besada, V., Schultze, F., 2002. Mercury concentrations in seawater, sediments and wild mussels from the coast of Galicia (NW Spain). Marine Pollution Bulletin 44, 345-349.

- Bettencourt, A.M., Bricker, S.B., Ferreira, J.G., Franco, A., Marques, J.C., Melo, J.J., Nobre, A., Ramos, L., Reis, C.S., Salas, F., Silva, M.C., Simas, T., Wolff, W.J., 2003. Typology and Reference Conditions for Portuguese Transitional and Coastal Waters, Development of Guidelines for the Application of the European Union Water Framework Directive. Instituto da Água and Institute of Marine Research. 119pp. 
- Boyle, E.A., Huested, S.S., Jones, S.P., 1981. On the distribution of $\mathrm{Cu}, \mathrm{Ni}$, and $\mathrm{Cd}$ in the surface waters of the North Atlantic and North Pacific Ocean. Journal of Geophysical Research 86, 8048-8066.

- Boutier, B., Chiffoleau, J.F., Gonzalez, J.L., Lazure, P., Auger, D., Truquet, I., 2000. Influence of the Gironde estuary outputs on cadmium concentrations in the coastal waters: consequences on the Marennes-Oleron bay (France). Oceanologica Acta 23, 745-757.

- Braungardt, C., Achterberg, E.P., Nimmo, M., 1998. On-line voltammetric monitoring of dissolved $\mathrm{Cu}$ and $\mathrm{Ni}$ in the Gulf of Cadiz, south-west Spain. Analytica Chimica Acta 377, 20515.

- Brogueira, M.J., Cabeçadas, G., Gonçalves, C., 2004. Chemical resolution of a meddy emerging off southern Portugal. Continental Shelf Research 24, 1651-1657.

- Bruland, K.W., Knauer, G.A., Martin, J.H., 1978. Cadmium in northeast Pacific waters. Limnology and Oceanography 23, 119-128.

- Bruland, K.W., Franks, R.P., 1983. Mn, Ni, Cu, Zn, and Cd in the western North Atlantic, in: Wong, C.S., Boyle, E., Bruland, K.W., Burton, J.D., Goldberg, E.D. (Eds.). Trace Metals in Seawater. Plenum Press, New York, pp. 505-512.

- Bruland, K.W., 1992. Complexation of cadmimum by natural organic igands in the central North Pacific, Limnology and Oceanography 37, 1008.

- Caetano, M., Vale, C., 2003. Trace-elemental composition of seston and plankton along the Portuguese coast. Acta Oecologica 24, S341-S349.

- Cross-Calibrated Multi-Platform (CCMP) Ocean Surface Wind Components (Atlas et al. 2008, 2009). http://podaac-www.jpl.nasa.gov/datasetlist?search=ccmp

- Chiffoleau, J.F., Cossa, D., Auger, D., Truquet, I., 1994. Trace metal distribution, partition and and fluxes in the Seine estuary (France) in low discharge regime. Marine Chemistry 47, 145158.

- Chiffoleau, J.F., Auger, D., Chartier, E., 1999. Fluxes of selected trace metals from the Seine estuary to eastern English channel during the period August 1994 to July 1995. Continental Shelf Research 19, 2063-2082.

- Chiffoleau, J.F., Chauvaud, L., Amouroux, D., Barats, A., Dufour, A., Pécheyran, C., Roux, N., 2004. Nickel and vanadium contamination of benthic invertebrates following the Erika wreck. Aquatic Living Resources 17, 273-280.

- Cobelo-García, A., Prego, R., DeCastro, M., 2005. Metal distributions and their fluxes at the coastal boundary of a semi-enclosed ria. Marine Chemistry 51, 161-176.

- Comans, R.N.J., Van Dijk, C., Van der Weijden, C.H., 1988. Adsorption/desorption behavior of cadmium on natural suspended particles under freshwater conditions and at increased salinity. Chem. Geol. 70, 194.

- Cossa, D., Cotté-Krieff, M.H., Mason, R.P., Bretaudeau-Sanjuan, J., 2004. Total mercury in the water column near the shelf edge of the European continental margin. Marine Chemistry 90 , 21-29.

- Cossa, D., Elbaz-Poulichet, F., Nieto, J.M., 2001. Mercury in the tinto-odiel estuarine system (Gulf of Cadiz, Spain): Sources and dispersion. Aquatic Geochemistry 7, 1-12.

- Cossa, D., Fileman, C., 1991. Mercury concentrations in surface waters of the English channel. A cooperative study. Marine Pollution Bulletin 22, 197-200.

- Cossa, D., SanJuan, J., Noel, J., 1994. Mercury transport in waters of the Strait of Dover. Marine Pollution Bulletin 28, 385-388.

- Cotté-Krief, M.H., Guieu, C., Thomas, A.J., Martin, J.M., 2000. Sources of Cd, Cu, Ni and Zn in Portuguese coastal waters. Marine Chemistry 71, 199-214.

- Cottè-Krief, M.H., Thomas, A.J., Martin, J.M., 2002. Trace metal (Cd, Cu, Ni and Pb) cycling in the upper water column near the shelf edge of the European continental margin (Celtic Sea). Marine Chemistry 79, 1-26. 
- Delgado, J., Sarmiento, A.M., de Melo, M.T.C., Nieto, J.M., 2009. Environmental impact of mining activities in the southern sector of the Guadiana Basin (SW of the Iberian Peninsula). Water Air and Soil Pollution 199, 323-341.

- Elbaz-Poulichet, F., Braungardt, C., Achterberg, E., Morley, N., Cossa, D., Beckers, J.M., Nomérange, P., Cruzado, A., Leblanc, M., 2001. Metal biogeochemistry in the Tinto-Odiel rivers (Southern Spain) and in the Gulf of Cadiz: a synthesis of the results of TOROS project. Continental Shelf Research 21, 1961-1973.

- Ellwood, M.J., van den Berg, C.M.G., 2001. Determination of organic complexation of cobalt in seawater by cathodic stripping voltammetry. Marine Chemistry 75, 33-47.

- Ellwood, M.J., van den Berg, C.M.G., 2000. Zinc speciation in the Northeastern Atlantic Ocean. Marine Chemistry 68, 295-306.

- EPA Method 1631. Measurement of Mercury in Water. http://water.epa.gov/scitech/methods/cwa/metals/mercury/index.cfm.

- Ferreira, J.G., Simas, T., Nobre, A., Silva, M.C., Shifferegger, K., Lencart-Silva, J., 2003. Identification of sensitive areas and vulnerable zones in transitional and coastal Portuguese systems. Application of the United States National Estuarine Eutrophication Assessment to the Minho, Lima, Douro, Ria de 624 Aveiro, Mondego, Tagus, Sado, Mira, Ria Formosa and Guadiana systems. Instituto da Água and Institute of Marine Research, pp. 168.

- Fileman, C.F., Althaus, M., Law, R.J., 1991. Dissolved and particulate trace metals in surface waters over the Dogger Bank, Central North Sea. Marine Pollution Bulletin 22, 241-244.

- Fiuza, A., 1983. Upwelling patterns off Portugal, in: Suess, E., Thide, J. (Eds.). Coastal Upwelling, its Sediment Record. Responses of Sedimentary Regime to Present Coastal Upwelling, Plenum, pp. 85-98.

- Frouin, R., Fiuza, A., Ambar, I., Boyd, T., 1990. Observations of a poleward surface current off the coasts of Portugal and Spain during winter. Journal of Geophysical Research 95, 679691.

- García-Lafuente, J., Delgado, J., Criado Aldeanueva, F., Bruno, M., Del Río, J., Vargas, J.M., 2006. Water mass circulation on the continental shelf of the Gulf of Cadiz. Deep-Sea Research II 53, 1182-1197.

- Gardiner, J., Stiff, M.J., 1975. The determination of cadmium, lead, copper and zinc in ground water, estuarine water, sewage and sewage effluent by anodic stripping voltammetry. Water Research. 9, 517-523.

- GeoNames geographical database. www.geonames.org.

- Grimalt, J.O., Ferrer, M., Macpherson, E., 1999. The mine tailing accident in Aznalcollar. Science of the Total Environment. 242: 3-11.

- Hansen, H.P., Grasshoff, K., 1983. Procedures for the automated determination of seawater constituents, in: Grasshoff, K., Ehrhardt, M., Kremling, K. (Eds.). Methods of seawater analysis: second, revised and extended edition. Verlag Chemie, Weinheim, pp. 362-379.

- INAG. Instituto da Agua. www.inag.pt

- James, R.H., Statham, P.J., Morley, N.H., Burton, J.D., 1993. Aspects of the geochemistry of dissolved and particulate $\mathrm{Cd}, \mathrm{Cu}, \mathrm{Ni}, \mathrm{Co}$ and $\mathrm{Pb}$ in the Dover Strait. Oceanologica Acta 16, 553-564.

- Klinkhammer, G., Heggie, D.T., Graham, D.W., 1982. Metal diagenesis in oxic marine sediments. Earth and Planetary Science Letters, 61, 211-19.

- Kremling, K., 1985. The distribution of $\mathrm{Cd}, \mathrm{Cu}, \mathrm{Ni}, \mathrm{Mn}$ and $\mathrm{Al}$ in the surface waters of the open Atlantic and European shelf area. Deep-Sea Res. 32, 531-555.

- Kremling, K., Hydes, D., 1988. Summer distributions of dissolved $\mathrm{Al}, \mathrm{Cd}, \mathrm{Co}, \mathrm{Cu}, \mathrm{Mn}$ and $\mathrm{Ni}$ in surface waters around the British Isles. Continental Shelf Research 8, 89-105.

- Kremling, K., Pohl, C., 1989. Studies on the spatial and seasonal variability of dissolved Cd, Co and $\mathrm{Ni}$ in the North-east Atlantic surface waters. Marine Chemistry 27, 43-60. 
- Kuss, J., Kremling, K., 1999. Spatial variability of particle associated trace elements in nearsurface waters of the North Atlantic (30 degrees N/60 degrees W to 60 degrees N/2 degrees W), derived by large-volume sampling. Marine Chemistry 68, 71-86.

- Landing, W.M., Cutter, G.A., Dalziel, J.A., Flegal, A.R., Powell, R.T., Schmidt, D., Shiller, A., Statham, P., Westerlund, S., Resing, J., 1995. Analytical intercomparison results from the 1990 intergovernmental oceanographic commission open ocean baseline survey for trace metals: Atlantic Ocean. Marine Chemistry 49, 253-265.

- Laslett, R.E., 1995. Concentrations of dissolved and suspended particulate $\mathrm{Cd}, \mathrm{Cu}, \mathrm{Mn}, \mathrm{Ni}, \mathrm{Pb}$ and $\mathrm{Zn}$ in surface waters around the coasts of England and wales and in adjacent seas. Estuarine Coastal and Shelf Science 40, 67-85.

- Leermakers, M., Galletti, S., De Galan, S., Brion, N., Baeyens, W., 2001. Mercury in the southern North Sea and Scheldt estuary. Marine Chemistry 75, 229-248.

- Le Gal, A.C., Hydes, D.J., Statham, P.J., Morley, N.H., Hunt, C.L., 1999. Procceses influencing distribution and concentrations of $\mathrm{Cd}, \mathrm{Cu}, \mathrm{Mn}$ and $\mathrm{Ni}$ in the North West European Shelf break. Marine Chemistry 68, 97-115.

- Leistel, J., Marcoux, E., Thieblemont, D., Quesada, C., Sanchez, A., Almodovar, G., Pascual, E., Saez, R., 1998. The volcanic-hosted massive sulphide deposits of the Iberian Pyrite Belt. Mineralium Deposita 33, 2-30.

- Lorenzen, C.J., 1967. Vertical distribution of chlorophyll and phaeo-pigments: Baja California. Deep-Sea Research Oceanography Abstracts 14, 735-745.

- Loring, D.H., 1990. Lithium - a new approach for the granulometric normalization of trace metal data. Marine Chemistry 29, 155-168.

- Martin, J.M., Meybeck, M., 1979. Elemental mass-balance of material carried by major world rivers. Marine Chemistry 7, 173-206.

- Martin, J.M., Whitfield, M., 1983. The significance of the river input of chemical elements to the ocean, in: Wong, C.S., Boyle, E., Bruland, K.W., Burton, J.D., Goldberg, E.D., (Eds.). Trace Metals in Seawater. Plenum Press, New York, pp. 265-296.

- Martin, J.M., Elbaz-Poulichet, F., Guieu, C., Loye-Pilot, M.D., Han, G., 1989. River versus atmospheric input of material to the Mediterranean Sea: an overview. Marine Chemistry 28, 159-182.

- Martins, M., Ferreira, A.M., Vale, C., 2005. PCB composition in flood material and sediments from the Guadiana River estuary. Ciencias Marinas 31, 285-291.

- Mauritzen, M., Morel, Y., Paillet, J., 2001. On the influence of the Mediterranean Water on the central waters of the North Atlantic Ocean. Deep-Sea Research I 48, 347-381.

- Millward, G.E., Turner, A., 1995. Trace metals in estuaries. in: Salbu, B., Steiness, E., (Eds.). Trace elements in Natural Waters. CRC Press, Boca Raton, FL, pp. 223-245.

- Moita, M., 2001. Estrutura, Variabilidade e Dinamica do Fitoplancton na costa de Portugal continental. Ph.D. Thesis, $272 \mathrm{pp}$.

- Moita, M.T., Oliveira, P.B., Mendes, J.C., Palma, A.S., 2003. Distribution of chlorophyll a and Gymnodinium catenatum associated with coastal upwelling plumes off central Portugal. Acta Oecologica 24, S125-S132.

- Morris, A.W., Bale, A.J., Howland, R.J.M., Millward, G.E., Ackroyd, D.R., Loring, D.H., Rantala, R.T.T., 1986. Sediment mobility and its contribution to trace metal cycling and retention in a macrotidal estuary. Water Science and Technology 18, 111-119.

- Muller, F.L.L., 1996. Interactions of copper, lead and cadmium with the dissolved, colloidal and particulate components of estuarine and coastal waters. Marine Chemistry 52, 245268.

- Munha, J., Barriga, F.J.A.S., Kerrich, R., 1986. High 180- forming fluids in volcanic-hosted base and metal massive sulfide deposits: Geologic of ${ }^{18} \mathrm{O} /{ }^{16} \mathrm{O}$, and $\mathrm{D} / \mathrm{H}$ evidence for the Iberian pyrite belt; Crandon, Wisconsin, and Blue Hill, Maine: Economic Geology v. 81, p. 530-552. 
- Olsen, C.R., Cutshall, N.H., Larsen, I.L., 1982. Pollutant-particle associations and dynamics in coastal marine environments: a review. Marine Chemistry 11, 501-533.

- Pato, P., Otero, M., Valega, M., Lopes, C.B., Pereira, M.E., Duarte, A.C., 2010. Mercury partition in the interface between a contaminated lagoon and the ocean: The role of particulate load and composition. Marine Pollution Bulletin 60, 1658-1666.

- Prego, R., Cobelo-García, A., 2003. Twentieth century overview of heavy metals in the Galician Rias (NW Iberian Peninsula). Environmental Pollution 121, 425-452.

- Quental, T., Ferreira, A.M., Vale, C., 2003. The distribution of PCBs and DDTs in seston and plankton along the Portuguese coast. Acta Oecologica 24, S333-S339.

- Relvas, P., Barton, E.D., 2002. Mesoscale patterns in the Cape Sao Vicente (Iberian Peninsula) upwelling region. Journal of Geophysical Research 107, 3164.

- Relvas, P., Barton, E.D., Dubert, J., Oliveira, P.B., Peliz, A., daSilva, J.C.B., Santos, A.M.P., 2007. Physical oceanography of the western Iberia ecosystem: Latest views and challenges. Progress in Oceanography 74, 149-173.

- Saager, P.M., deBaar, H.J.W., deJong, J.T.M., Nolting, R.F., Schijf, J., 1997. Hydrography and local sources of dissolved trace metals $\mathrm{Mn}, \mathrm{Ni}, \mathrm{Cu}$, and $\mathrm{Cd}$ in the northeast Atlantic Ocean. Marine Chemistry 57, 195-216.

- Santos-Echeandía, J., Prego, R., Cobelo-García, A., 2005. Copper, nickel, and vanadium in the Western Galician Shelf in early spring after the Prestige catastrophe: is there seawater contamination? Analytical Bioanalytical Chemistry 382, 360-365.

- Santos-Echeandía, J., Prego, R., Cobelo-García, A., 2008. Influence of the heavy fuel spill from the Prestige tanker wreckage in the overlying seawater column levels of copper, nickel and vanadium (NE Atlantic ocean). Journal of Marine Systems 72: 350-357.

- Santos-Echeandía, J., Prego, R., Cobelo-García, A., 2009. Intra-annual variation and baseline concentrations of dissolved trace metals in the Vigo Ria and adjacent coastal waters (NE Atlantic Coast). Marine Pollution Bulletin 58, 298-303.

- Santos-Echeandía, J., 2011. Direct simultaneous determination of $\mathrm{Co}, \mathrm{Cu}, \mathrm{Fe}, \mathrm{Ni}$ and $\mathrm{V}$ in pore waters by means of adsorptive cathodic stripping voltammetry with mixed ligands. Talanta 85, 506-512.

- Sarmiento, A.M., DelValls, A., Nieto, J.M., Salamanca, M.J., Caraballo, M.A., 2011. Toxicity and potential risk assessment of a river polluted by acid mine drainage in the Iberian Pyrite Belt (SW Spain). Science of the Total Environment 409, 4763-4771.

- Schmidt, 1992. Mercury in Baltic and North Sea waters. Water Air and Soil Pollution 62, 4355.

- Statham, P.J., Burton, J.D., Hydes, D.J., 1985. Cd and Mn in the Alboran Sea and adjacent North Atlantic: geochemical implications for the Mediterranean. Nature 313, 565-567.

- Statham, P.J., Auger, Y., Burton, J.D., Choisy, P., Fischer, J.C., James, R.H., Morley, N.H., Ouddane, B., Puskaric, E., Wartel, M., 1993. Fluxes of $\mathrm{Cd}, \mathrm{Co}, \mathrm{Cu}, \mathrm{Fe}, \mathrm{Mn}, \mathrm{Ni}, \mathrm{Pb}$ and $\mathrm{Zn}$ through the Strait of Dover into the Southern North Sea. Oceanologica Acta 16, 541-552.

- Statham, P.J., Leclercq, S., Hart, V., Batte, M., Auger, Y., Wartel, M., Cheftel, J., 1999. Dissolved and particulate trace metal fluxes through the central English Channel, and the influence of coastal gyres. Continental Shelf Research 19, 2019-2040.

- Stumm, W., Morgan, J.J., 1981. Aquatic Chemistry. Wiley Interscience, New York.

- Tueros, I., Rodríguez, J.G., Borja, A., Solaun, O., Valencia, V., Millán, E., 2008. Dissolved metal background levels in marine waters, for the assessment of the physico-chemical status, within the European Water Framework Directive. Science of the Total Environment 407, 4052.

- Vale, C., Sundby, B., 1987. Suspended sediment fluctuations in the Tagus estuary on semidiurnal and fortnightly time scales. Estuarine Coastal and Shelf Science 25, 495-508. 
- Vale, C., 1990. Temporal variations of particulate metals in the Tagus River Estuary. Science of the Total Environment 97/98, 137-154.

714 - van Geen, A., Rosener, P., Boyle, E.A., 1988. Entrainment of trace metal-enriched Atlantic shelf waters in the inflow of the Mediterranean Sea. Nature 331, 423-426.

716 - van Geen, A., Boyle, E.A., Moore, W.S., 1991. Trace metal enrichments in waters of the Gulf of Cadiz, Spain. Geochimica et Cosmochimica Acta 55, 2173-2191.

- van Geen, A., Boyle, E.A., Martin, J.M., 1990. Trace metal enrichments in coastal waters of the Iberian Peninsula. EOS, Transactions, American Geophysical Union 71.

720

- van Geen, A., Luoma, S.N., 1993. Trace-metals (Cd, Cu, Ni and $\mathrm{Zn})$ and nutrients in coastal waters adjacent to San Francisco Bay, California. Estuaries 16, 559-66.

- van Geen, A., Adkins, J.F., Boyle, E.A., Nelson, C.H., Palanques, A., 1997. A 120 yr record of widespread contamination from mining of the Iberian pyrite belt. Geology 25: 291-294.

- Waeles, M., Riso, R.D., Maguer, J.F., Le Corre, P., 2004. Distribution and chemical speciation of dissolved cadmium and copper in the Loire estuary and North Biscay continental shelf, France. Estuarine Coastal and Shelf Science 59, 49-57.

- Windom, H.L., Smith, R.G., Maeda, M., 1985. The geochemistry of lead in rivers, estuaries and the continental shelf of the southeastern United States. Marine Chemistry 17, 43-56.

- Windom, H.L., Smith, R.G., Rawlinson, C., 1989. Particulate trace metal composition and flux across the southeastern U.S. continental shelf. Marine Chemistry 27, 283-297.

- Wooster, W.S., Bakun, A., McLain, D.R., 1976. The seasonal upwelling cycle along the eastern boundary of the North Atlantic. Journal of Marine Research 34, 131-141. 
Table 1. Accuracy of the analytical procedure: AdCSV determination of Co and $\mathrm{Ni}$ and $\mathrm{ASV}$ of $\mathrm{Cd}, \mathrm{Cu}, \mathrm{Pb}$, and $\mathrm{Zn}$ in different certified reference materials (CASS-4: near-shore waters and SLEW-3: estuarine water) compared with the certified values. The value below concentrations represents the replicates.

\begin{tabular}{llcccccc}
\hline & & $\mathrm{Cd}$ & $\mathrm{Co}$ & $\mathrm{Cu}$ & $\mathrm{Ni}$ & $\mathrm{Pb}$ & $\mathrm{Zn}$ \\
& & $(\mathrm{nM})$ & $(\mathrm{nM})$ & $(\mathrm{nM})$ & $(\mathrm{nM})$ & $(\mathrm{nM})$ & $(\mathrm{nM})$ \\
\hline CASS-4 & Certified & $0.23 \pm 0.03$ & $0.44 \pm 0.05$ & $9.32 \pm 0.87$ & $5.35 \pm 0.51$ & $0.05 \pm 0.02$ & $5.83 \pm 0.87$ \\
& Obtained & $0.23 \pm 0.09$ & $0.42 \pm 0.11$ & $9.04 \pm 1.45$ & $5.44 \pm 0.77$ & $0.06 \pm 0.02$ & $5.85 \pm 1.49$ \\
& & $n=6$ & $n=5$ & $n=6$ & $n=6$ & $n=5$ & $n=6$ \\
\hline SLEW-3 & Certified & $0.43 \pm 0.04$ & $0.71 \pm 0.17$ & $24.39 \pm 1.89$ & $20.96 \pm 1.19$ & $0.04 \pm 0.01$ & $3.07 \pm 0.57$ \\
& Obtained & $0.38 \pm 0.04$ & $0.88 \pm 0.19$ & $25.92 \pm 3.71$ & $22.18 \pm 0.98$ & $0.06 \pm 0.03$ & $3.20 \pm 1.57$ \\
& & $n=5$ & $n=5$ & $n=4$ & $n=5$ & $n=5$ & $n=4$ \\
\hline
\end{tabular}


Table 2. Trace metal baseline concentrations (dissolved and particulate phases) for each typology defined in the Water Framework Directive for the Portuguese coast.

\begin{tabular}{|c|c|c|c|c|c|c|c|c|}
\hline Dissolved & & Cd (nM) & Co (nM) & $\mathrm{Cu}(\mathrm{nM})$ & Hg (pM) & Ni (nM) & $\mathrm{Pb}(\mathrm{nM})$ & Zn (nM) \\
\hline A7 & & $0.20-0.40$ & $1.50-1.80$ & 30-35 & $3-12$ & $9.0-12$ & $0.02-0.03$ & 17-21 \\
\hline Particulate & $\left.\mathrm{Al}(\mu \mathrm{mol} \mathrm{g})^{-1}\right)$ & Cd $\left(\mathrm{nmol} \mathrm{g}^{-1}\right)$ & Co $\left(\mathrm{nmol} \mathrm{g}^{-1}\right)$ & $\mathrm{Cu}\left(\mathrm{nmol} \mathrm{g}^{-1}\right)$ & $\mathrm{Hg}\left(\mathrm{nmol} \mathrm{g}^{-1}\right)$ & $\mathrm{Ni}\left(\mathrm{nmol} \mathrm{g}{ }^{-1}\right)$ & $\mathrm{Pb}\left(\mathrm{nmol} \mathrm{g}^{-1}\right)$ & $\mathrm{Zn}\left(\mathrm{nmol} \mathrm{g}^{-1}\right)$ \\
\hline A5 & $240-340$ & $0.3-0.4$ & $10-16$ & $53.0-114$ & $4.2-21$ & $35-56$ & $10.0-14.0$ & $420-590$ \\
\hline A6 & $36-135$ & $0.4-0.9$ & $2.0-6.0$ & $51.0-210$ & $4.0-11$ & $22-62$ & $11.0-28.0$ & $750-1250$ \\
\hline A7 & $122-124$ & $1.8-2.1$ & $7.0-13$ & $160-360$ & $2.8-3.1$ & $47-55$ & $122-138$ & $1000-1200$ \\
\hline
\end{tabular}


Table 3. Dissolved metal concentrations and ranges measured along the western European Atlantic coast and in the North Atlantic Ocean.

\begin{tabular}{|c|c|c|c|c|c|c|c|c|c|}
\hline Continental Shelf area & $\mathrm{Cd}(\mathrm{nM})$ & $\mathrm{Co}(\mathrm{nM})$ & $\mathrm{Cu}(\mathrm{nM})$ & $\mathrm{Hg}(\mathrm{pM})$ & $\mathrm{Ni}(\mathrm{nM})$ & $\mathrm{Pb}(\mathrm{nM})$ & $\mathrm{Zn}(\mathrm{nM})$ & N Stations & \\
\hline NE Atlantic Ocean & $0.02-0.19$ & $0.03-0.10$ & $0.6-2.7$ & $1-4$ & $0.5-3.6$ & $0.03-0.22$ & $0.1-3.0$ & 18 & (1) \\
\hline North Biscay shelf & $0.11-0.24$ & & $2.0-8.0$ & & & & & 33 & Waeles et al., 2004 \\
\hline English Channel & $0.09-0.25$ & $0.08-1.48$ & $2.0-7.0$ & $2-3$ & $2-14$ & $0.10-0.29$ & $2.0-15$ & 19 & $(2)$ \\
\hline Irish Sea & $0.12-0.72$ & $0.02-0.18$ & $3.0-24$ & & $2-15$ & $0.10-0.82$ & $3.0-54$ & 14 & (3) \\
\hline North Sea & $0.04-0.45$ & $0.11-0.59$ & 3.1-13 & $1-4$ & $3.1-17$ & $0.06-0.34$ & $1.7-34$ & 28 & (4) \\
\hline N Spanish Coast & & & $4.7-39$ & & $5.1-8.5$ & $1.45-7.24$ & $61-443$ & & Tueros et al., 2008 \\
\hline NW Spanish Coast & $0.01-0.08$ & $0.18-0.46$ & $0.7-8.2$ & $9-180$ & $1.3-5.2$ & $0.03-0.43$ & $0.8-6.3$ & 11 & Santos-Echeandía et al., 2005;2009; Beiras et al., 2002 \\
\hline Portuguese Coast & $0.01-0.89$ & $0.01-3.32$ & $0.9-45$ & $3-140$ & $1.9-15$ & $0.01-0.15$ & 1.4-62 & 46 & This study \\
\hline SW Spanish coast & $0.06-0.29$ & & $10-17$ & $2-4$ & $3-10$ & & $5.0-100$ & 31 & (5) \\
\hline
\end{tabular}

(1) Landing et al., 1995; Saager et al., 1997; Ellwood and van den Berg, 2000; Ellwood and van den Berg, 2001; Cotté-Krief et al, 2002, Cossa et al., 2004

(2) Kremling and Hydes, 1988; Laslett, 1995; Statham et al., 1999; Cossa and Fileman., 1991; Cossa et al., 1994

(3) Kremling and Hydes, 1988; Laslett, 1995; Achterberg and van den Berg, 1996.

(4) Laslett, 1995; Schmidt, 1992; Fileman et al., 1991; Leermakers et al., 2001

(5) Van Geen et al., 1991; van Geen et al., 1997 ; Braungardt et al., 1998; Achterberg et al., 1999 ; Elbaz-Poulichet et al., 2001 , Cossa et al., 2001 
Table 4. Particulate metal concentrations and ranges measured along the western European Atlantic coast and in the North Atlantic Ocean.

\begin{tabular}{|c|c|c|c|c|c|c|c|c|c|c|c|}
\hline Continental Shelf area & $\begin{array}{c}\mathrm{SPM} \\
\left(\mathrm{mg} \mathrm{L}^{-1}\right)\end{array}$ & $\begin{array}{c}\mathrm{Al} \\
\left.(\mu \mathrm{mol} \mathrm{g})^{-1}\right)\end{array}$ & $\begin{array}{c}\mathrm{Cd} \\
\left(\mathrm{nmol} \mathrm{g}^{-1}\right)\end{array}$ & $\begin{array}{c}\text { Co } \\
\left(\mathrm{nmol} \mathrm{g}^{-1}\right)\end{array}$ & $\begin{array}{c}\mathrm{Cu} \\
\left(\mathrm{nmol} \mathrm{g}^{-1}\right)\end{array}$ & $\begin{array}{c}\mathrm{Hg} \\
\left(\mathrm{nmol} \mathrm{g}^{-1}\right)\end{array}$ & $\begin{array}{c}\mathrm{Ni} \\
\left(\mathrm{nmol} \mathrm{g}^{-1}\right)\end{array}$ & $\begin{array}{c}\mathrm{Pb} \\
\left(\mathrm{nmol} \mathrm{g}^{-1}\right)\end{array}$ & $\begin{array}{c}\mathrm{Zn} \\
\left(\mathrm{nmol} \mathrm{g}^{-1}\right)\end{array}$ & N Stations & \\
\hline Portuguese Coast & $0.6-14$ & $36-2900$ & $0.03-15.1$ & $1.5-165$ & $51-614$ & $4.0-76.4$ & $22-1471$ & $10-306$ & $416-10981$ & 46 & This study \\
\hline SW Spanish coast & & & & & & $0.4-2.1$ & & & & 31 & Cossa et al., 2001 \\
\hline English Channel (Dover) & $0.7-19$ & $300-1400$ & $0.9-38.0$ & & $205-283$ & $2.1-8.8$ & $341-409$ & $70-320$ & $1162-4892$ & & (1) \\
\hline Irish Sea & & & $3.8-11.6$ & & $126-1338$ & & $204-647$ & $92-482$ & $2140-15000$ & 14 & Laslett, 1995 \\
\hline French Coast & $0.3-10$ & & $3.9-23.1$ & & & & & & & 15 & Boutier et al., 2000 \\
\hline North Sea & 0.2-0.9 & $17-230$ & $0.9-12.5$ & & $20-676$ & $0.1-1.6$ & $17-1073$ & $77-425$ & $1116-16820$ & 28 & Laslett , 1995; Fileman et al., 1991; Leermaker et al., 2001 \\
\hline North Atlantic & $0.1-0.4$ & $10-80$ & $24-150$ & $25-60$ & $150-660$ & & $100-350$ & $20-28$ & $250-950$ & 13 & Kuss and Kremling., 1999 \\
\hline
\end{tabular}

(1) James et al., 1993; Laslett, 1995; Statham et al., 1993; Cossa and Fileman., 1991 


\section{Figure Captions.}

Figure 1. Study area map with the a) surface water sampling stations and main river inputs and b) main capes and lithological facies.

Figure 2. Upwelling index conditions (in $\mathrm{m}^{3} \mathrm{~s}^{-1} \mathrm{~km}^{-1}$ ) during March 2010.

Figure 3. Satellite images for: a) Temperature, b) Salinity and c) Chlorophyll during the sampling cruise in the study area.

Figure 4. Master variables measured "in situ" at each sampling station during the campaign: a)

Temperature, b) Salinity, c) Chlorophyll, d) Dissolved oxygen and e) Suspended particulate matter.

Figure 5. Nutrient concentration at each station: a) Dissolved inorganic Nitrogen, b) Phosphate and c) Silicate.

Figure 6. Dissolved trace element concentration ranges along the Portuguese coastal waters.

Figure 7. Deep profile of Temperature, Salinity and dissolved trace metal concentrations in the DP sampling station (Figure 1). The Mediterranean Water mass is observed between $800-1200$ m depth.

Figure 8. Particulate trace element concentration ranges along the Portuguese coastal waters.

Figure 9. Trace metal to aluminum ratios in the particulate phase of the Portuguese coastal waters.

Figure 10. Principal component analysis for the dissolved trace metal levels along the Portuguese coast. 
Figure 1.

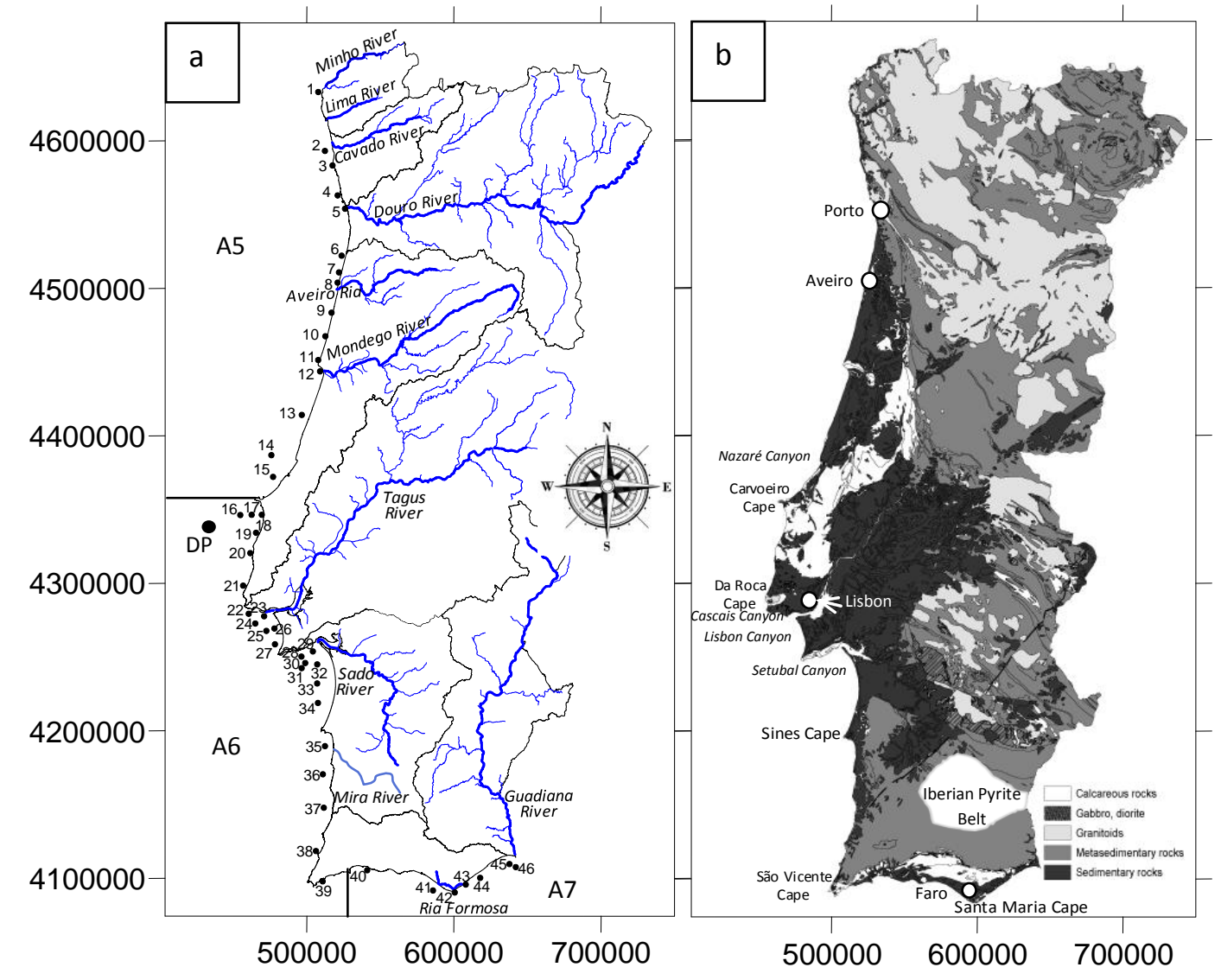


Figure2

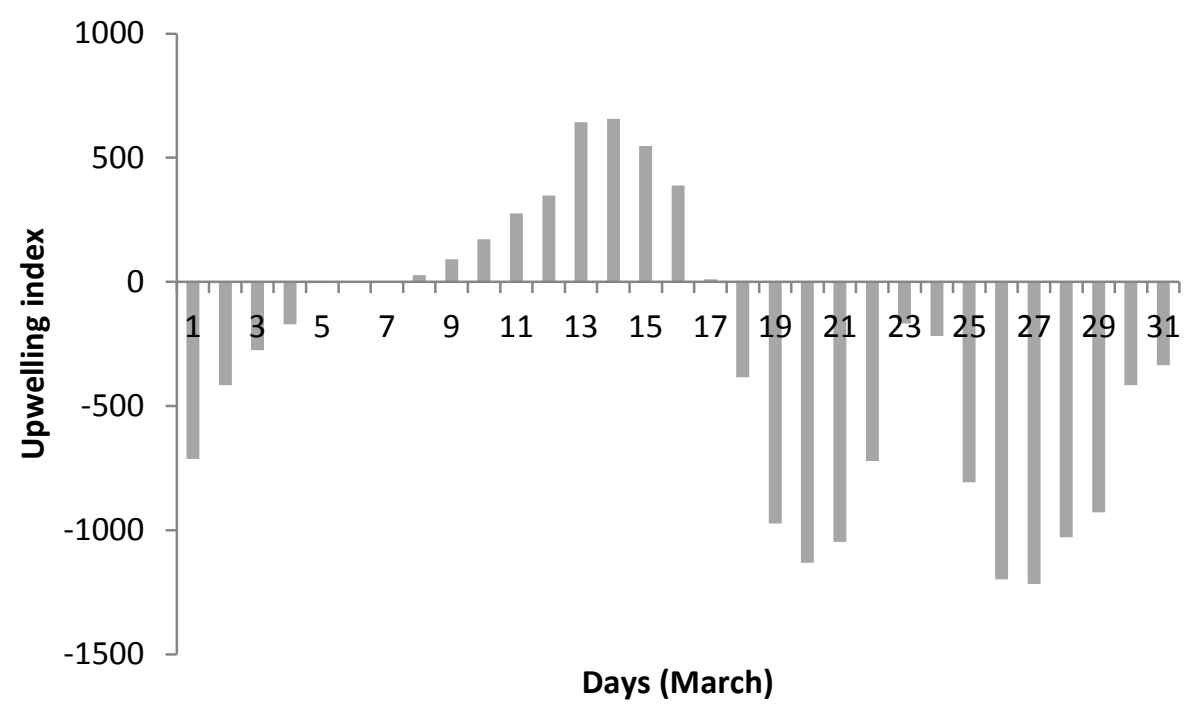

Figure 2 
Figure 3.

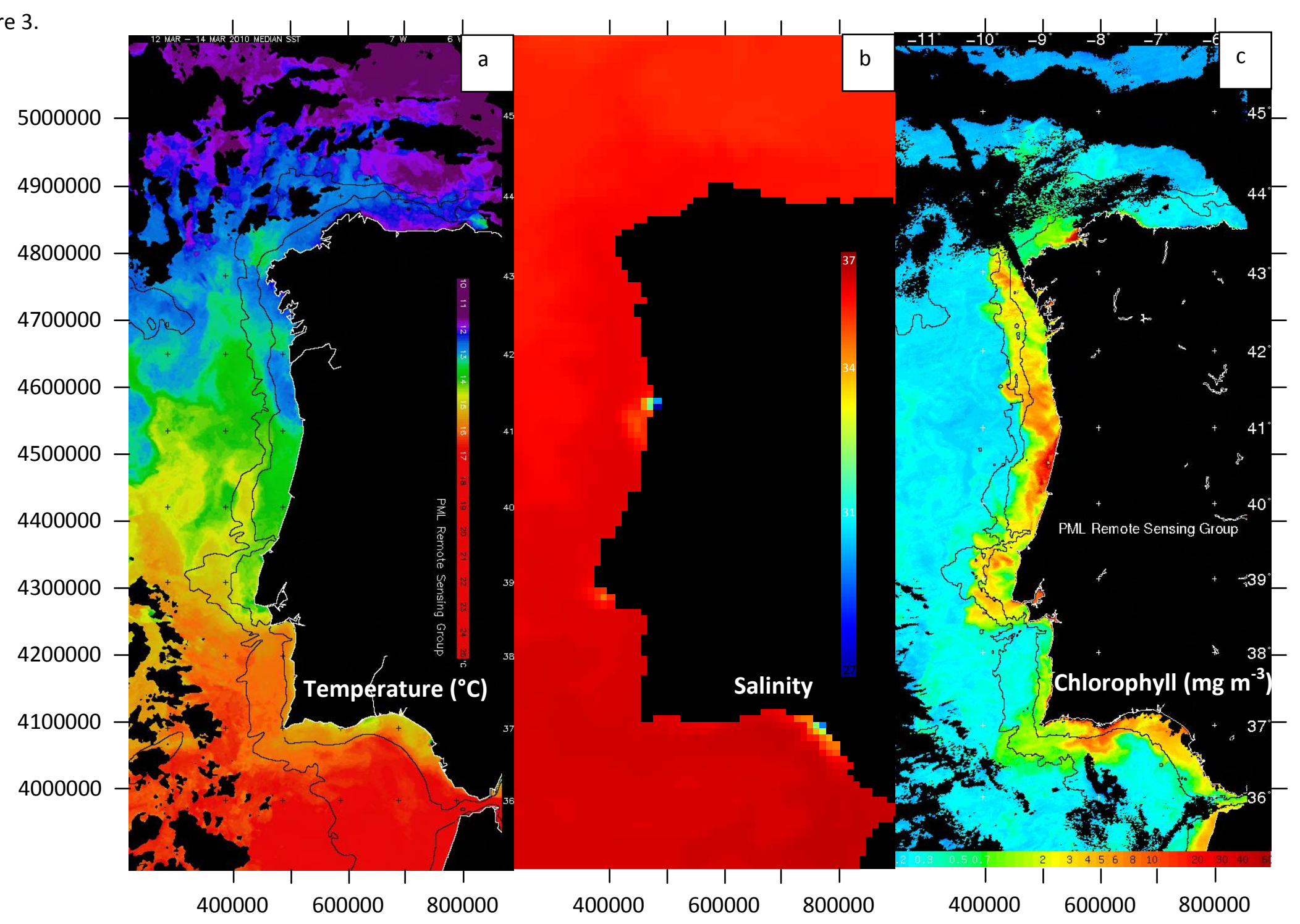



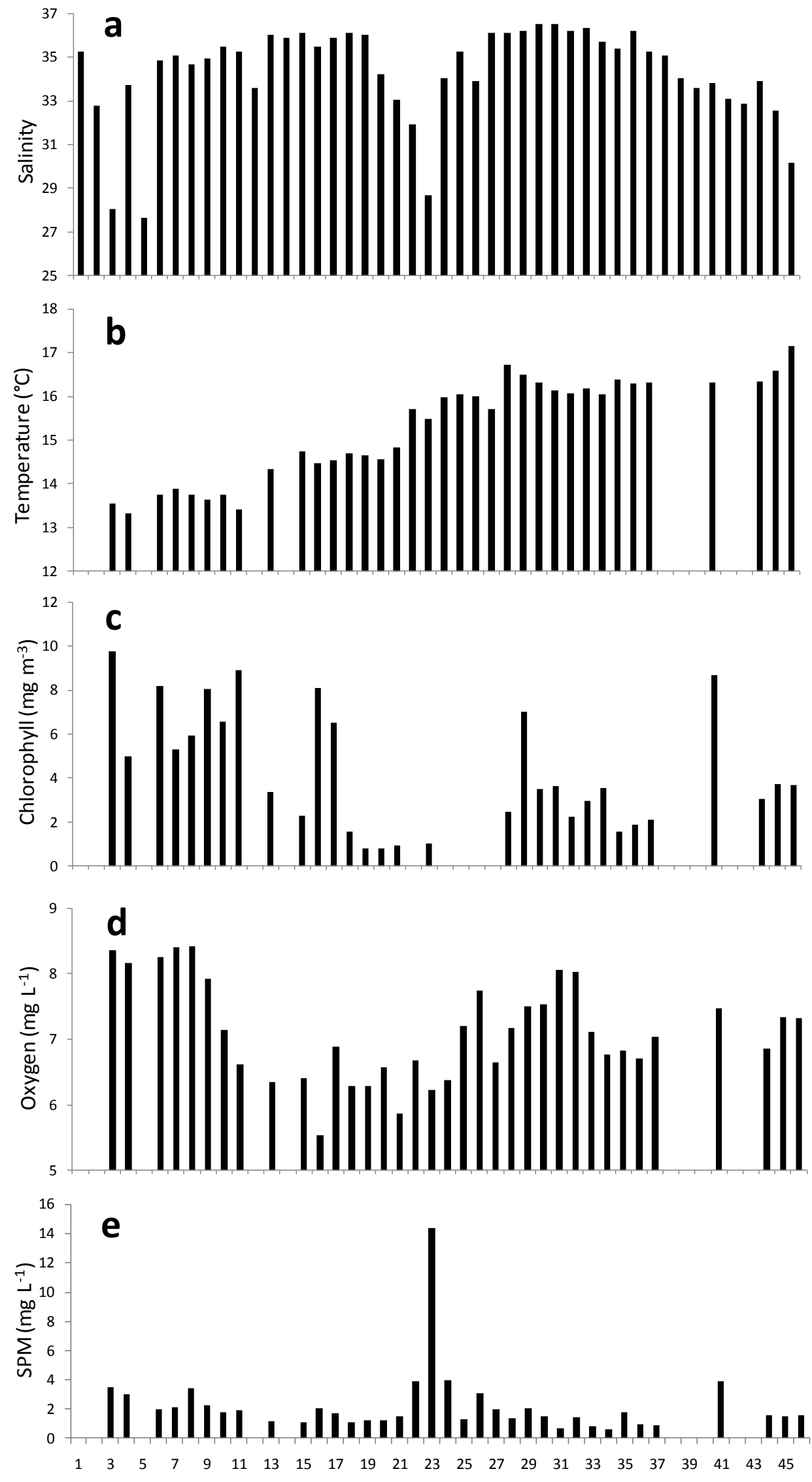

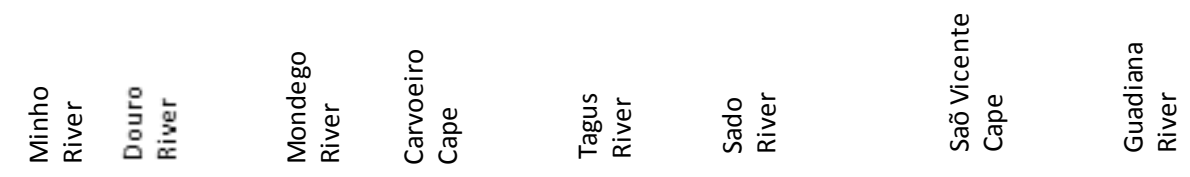


Figure 5
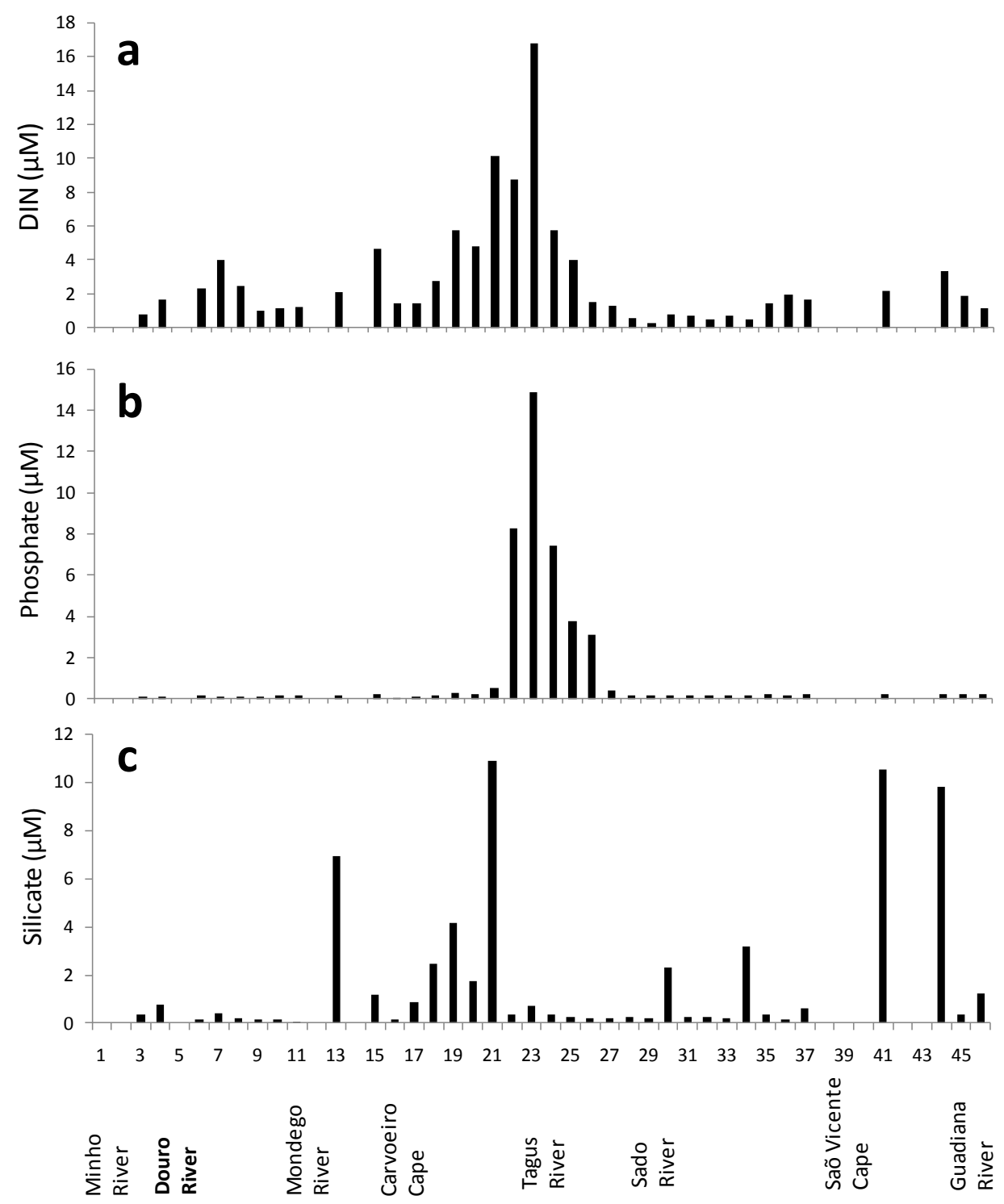


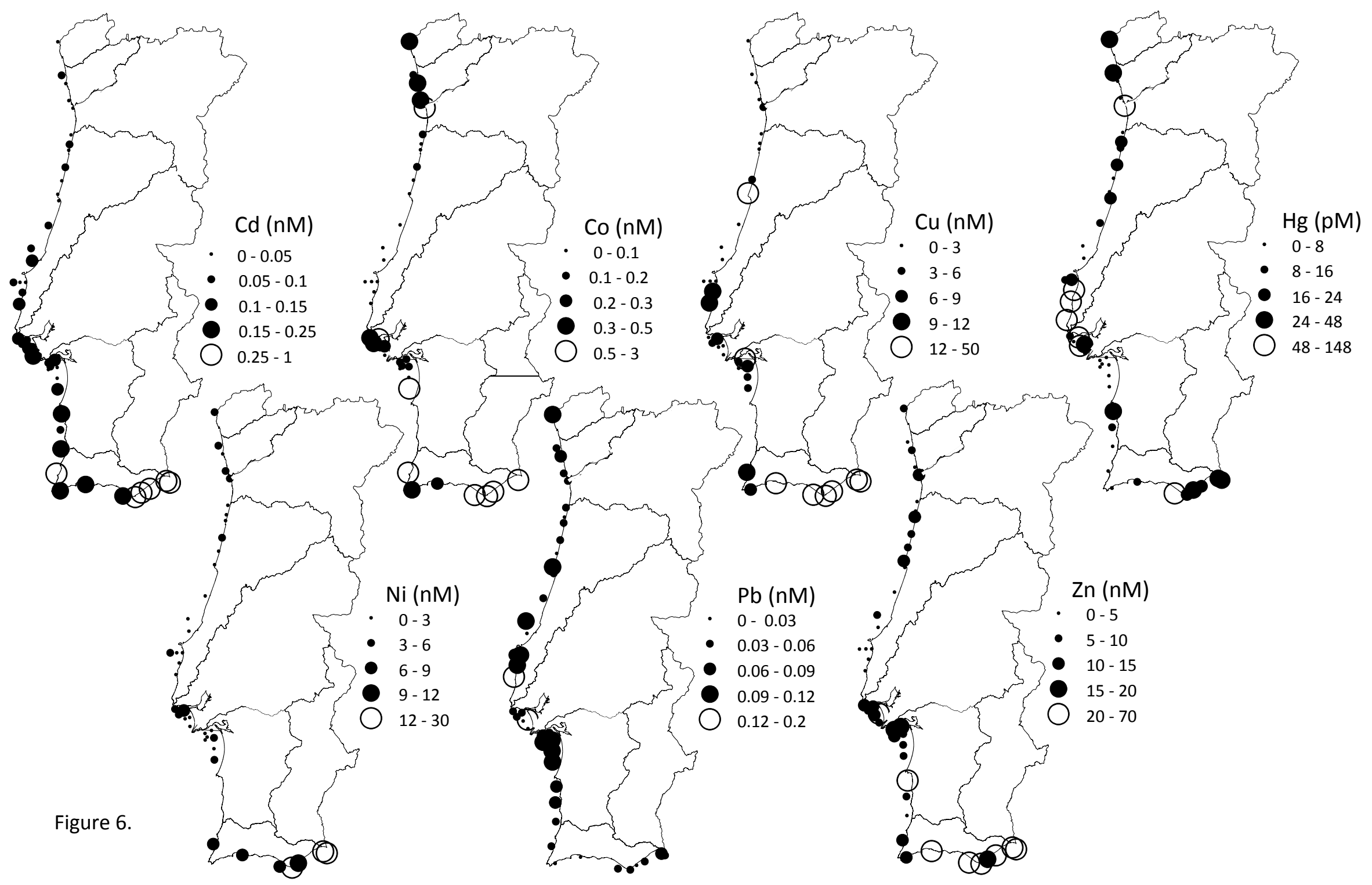


Figure 7.

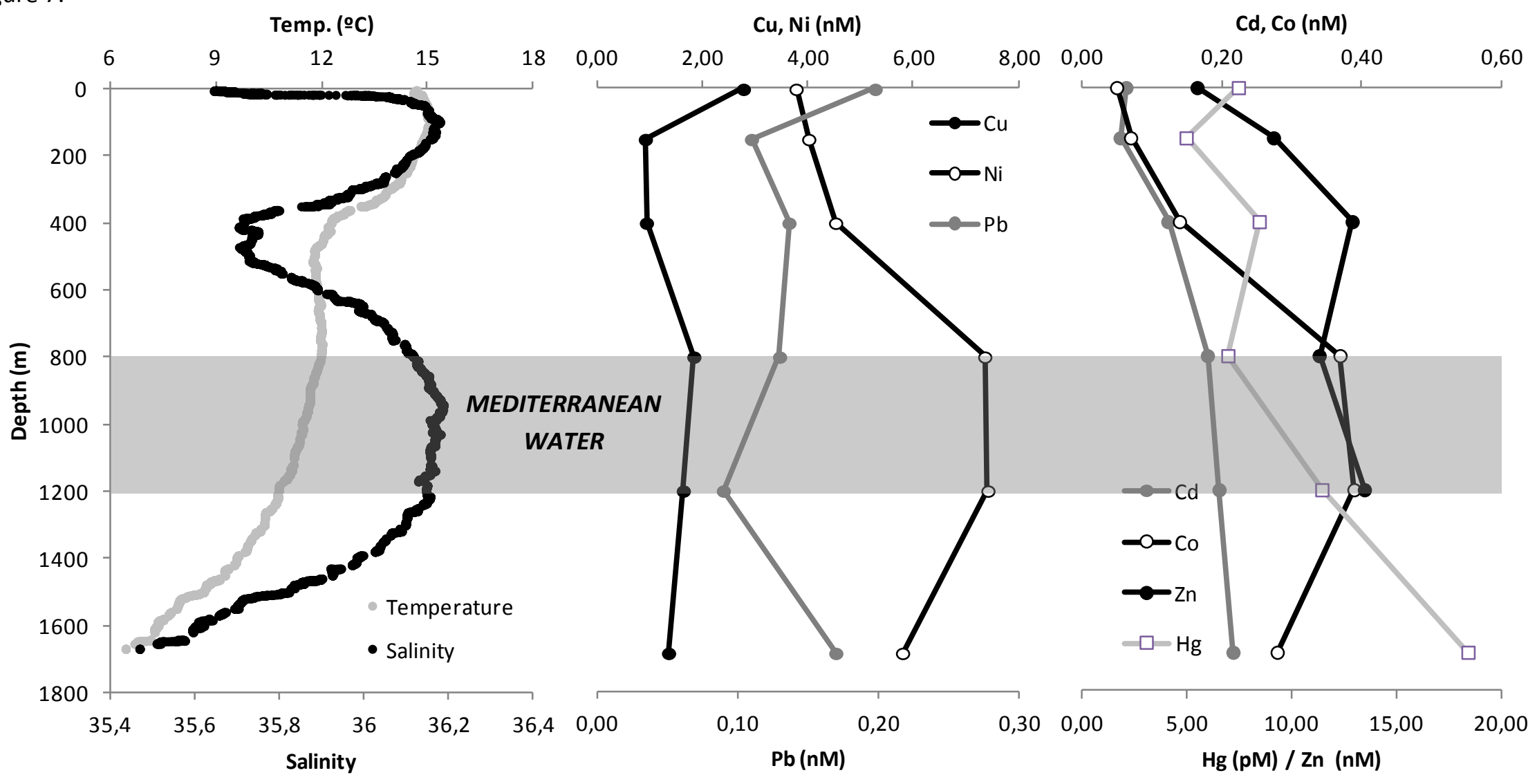




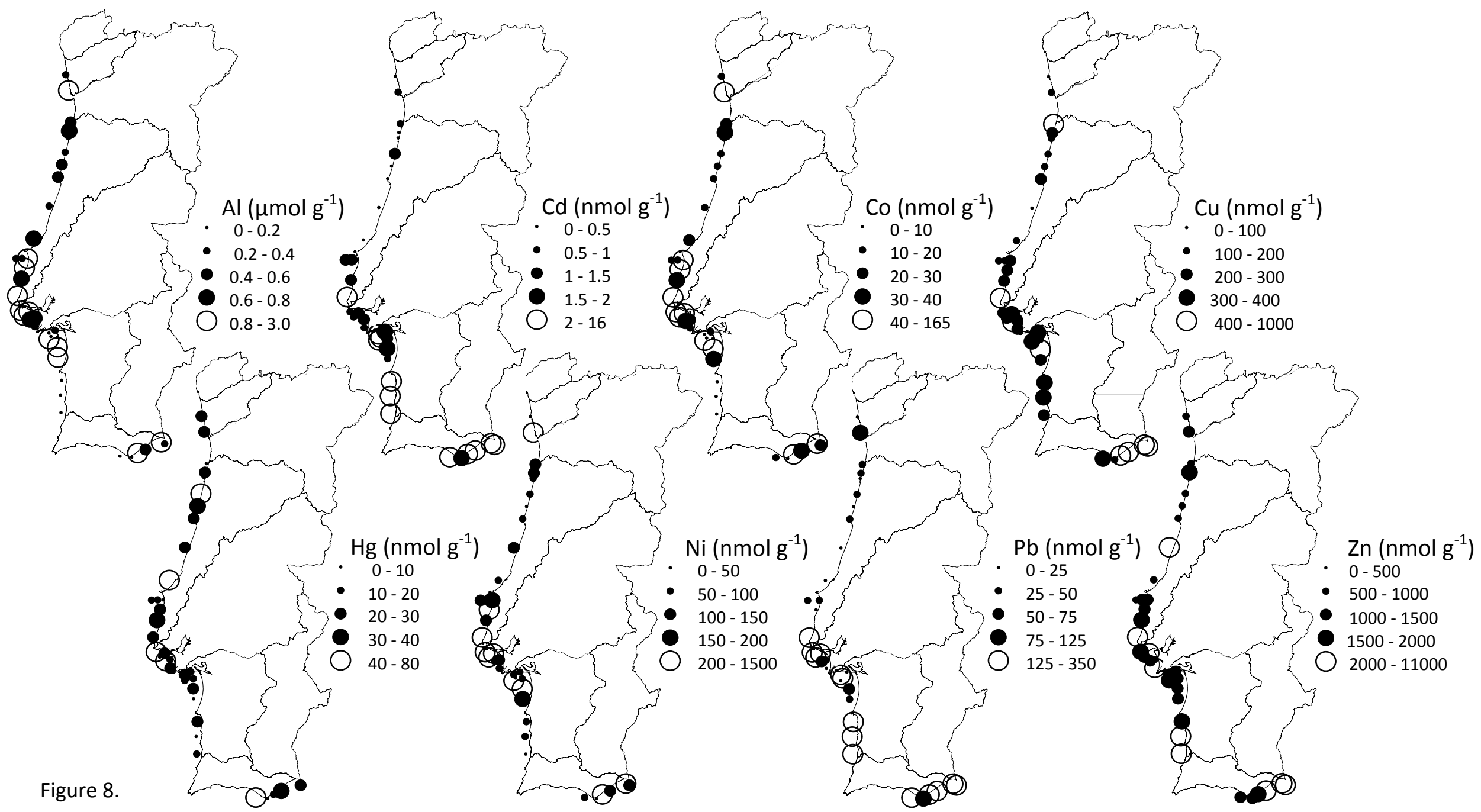




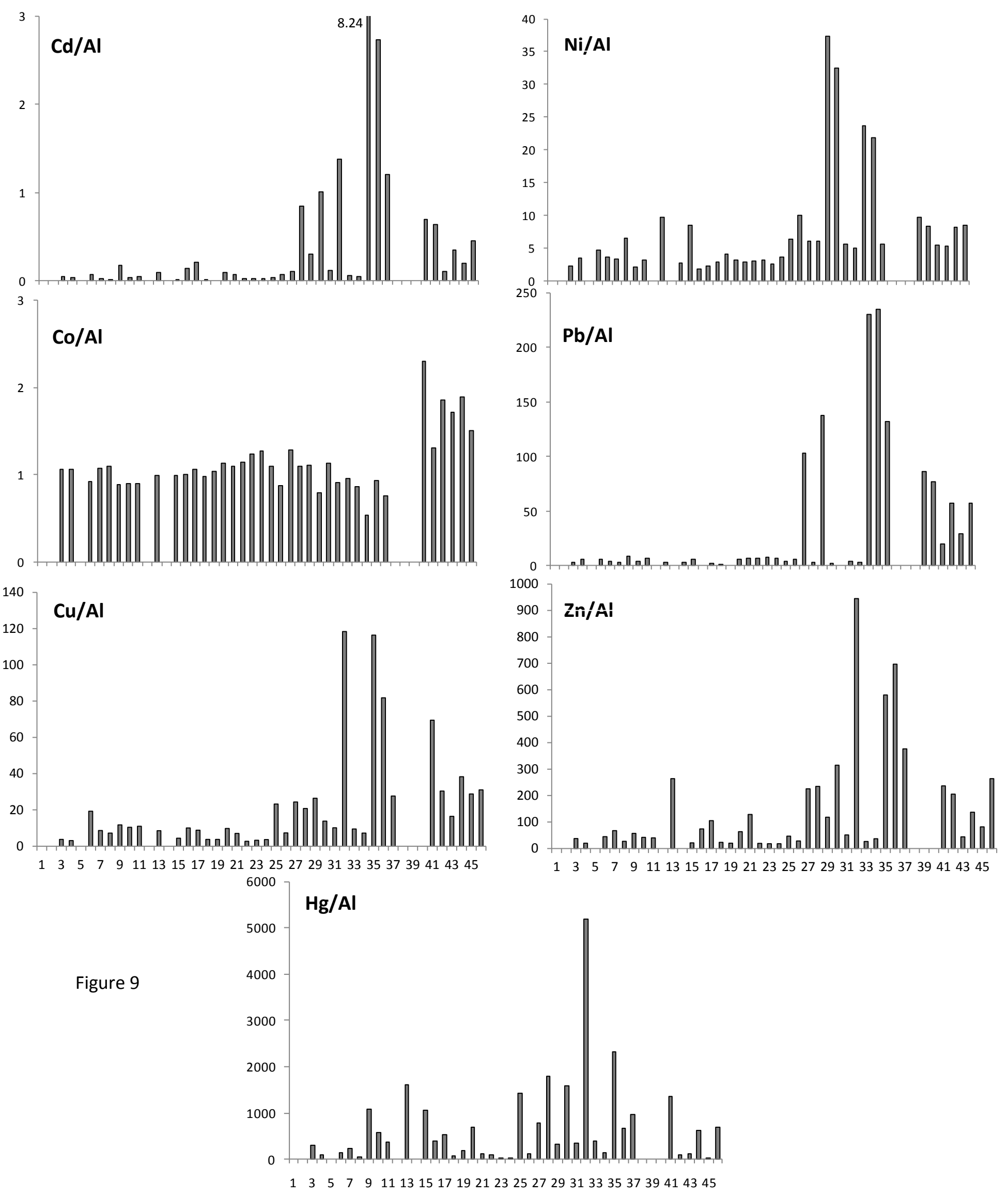


Figure 10.

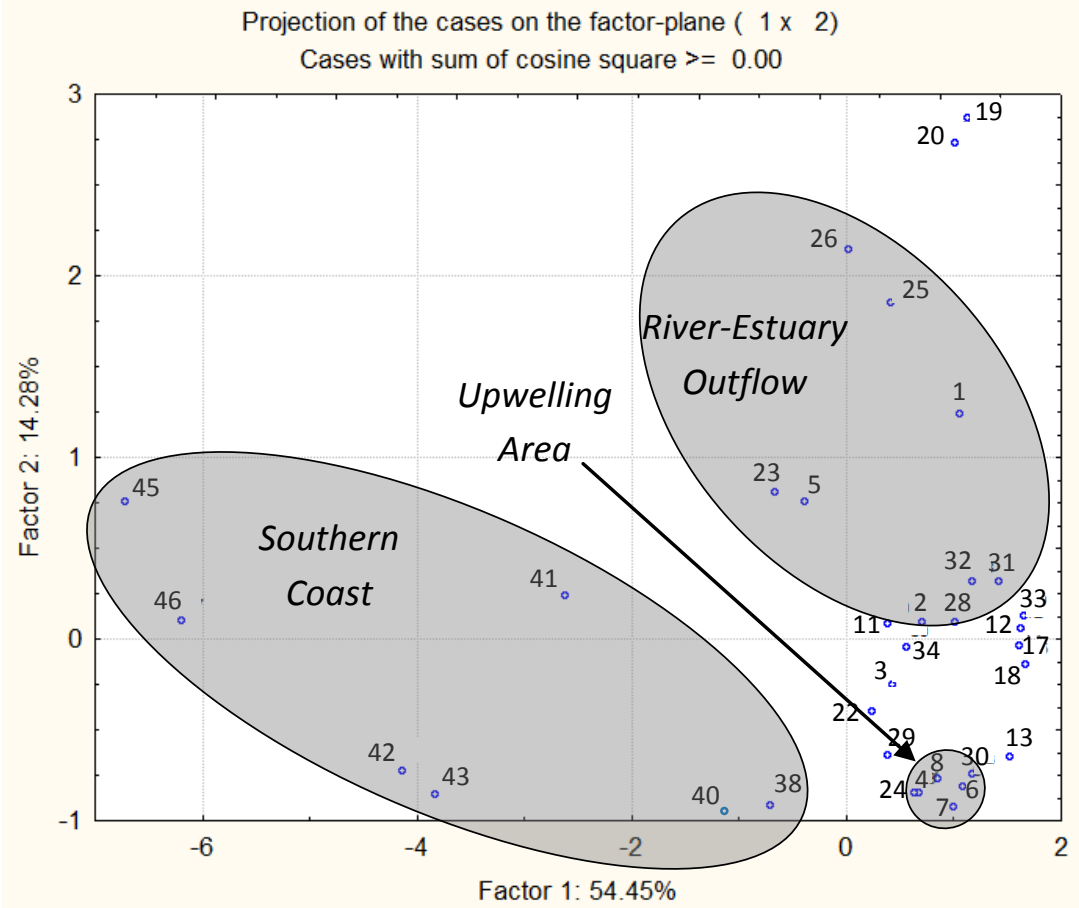


TableS1
Click here to download E-component: Tab.S1.docx Click here to download E-component: Tab.S1.docx

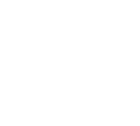

$\sqrt{2}$

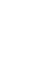

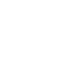

$\sqrt{2}$

(1)

(1)

(1)

(1)

(1)

(1)

(1)

.

.

.

.

.

.

.

.

.

.

.

.

.

.

. 
TableS2
Click here to download E-component: Tab.S2.doc Click here to download E-component: Tab.S2.doc 
TableS3
Click here to download E-component: Tab.S3.doc Click here to download E-component: Tab.S3.doc

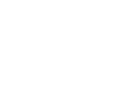

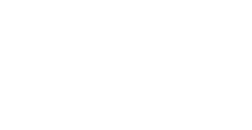
(1)

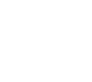
(1) (1) (1) (1)

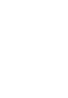
(1) (1) (1) (n)

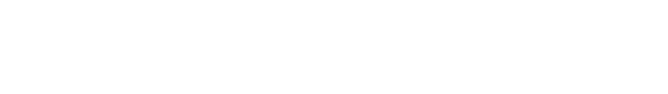

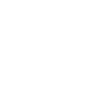
. . . . . . . .

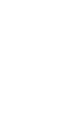
. (1)

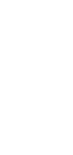

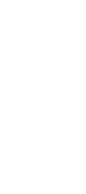

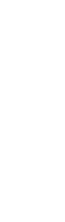

